University of Baltimore Law ScholarWorks@University of Baltimore School of Law

9-2009

\title{
Out-of-Court Statements: The Concentric Hoops of the Hearsay Rule and the Confrontation Clause
}

Lynn McLain

University of Baltimore, Imclain@ubalt.edu

Follow this and additional works at: http://scholarworks.law.ubalt.edu/all_fac

Part of the Evidence Commons

\section{Recommended Citation}

Lynn McLain, Out-of-Court Statements: The Concentric Hoops of the Hearsay Rule and the Confrontation Clause, (2009).

Available at: http://scholarworks.law.ubalt.edu/all_fac/915

This Conference Proceeding is brought to you for free and open access by the Faculty Scholarship at ScholarWorks@University of Baltimore School of Law. It has been accepted for inclusion in All Faculty Scholarship by an authorized administrator of ScholarWorks@University of Baltimore School of Law. For more information, please contact snolan@ubalt.edu. 


\section{Out-of-Court Statements: \\ The Concentric Hoops of the Hearsay Rule \\ and the Confrontation Clause}

Maryland Judicial Institute

September 2009

Professor Lynn McLain

University of Baltimore School of Law

\section{Contents}

$\underline{\text { Page }}$

I. Framework for Analysis of Whether an Out-of-Court Statement is Admissible ...... 1

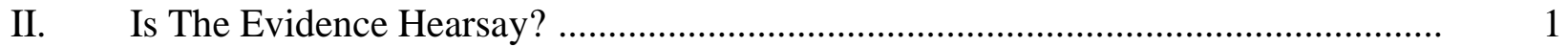

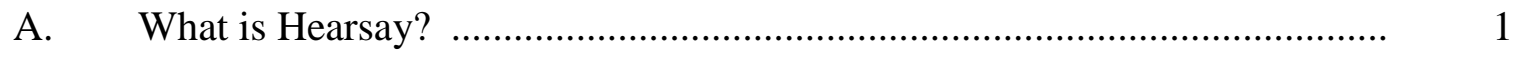

1. The Two Elements of "Out-of-Court" "Statement" ........................ 2

2. Making and Meeting Hearsay Objections .................................. 3

3. "TOMA"? or Nonhearsay? ….................................................. 3

4. Important Recent Maryland Decisions: Implied Assertions ............ 6

B. Evidence Offered for a Nonhearsay Purpose is Not Subject

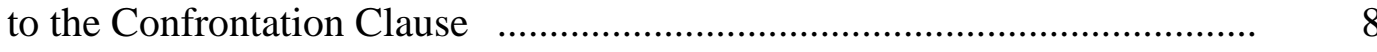

III. Admissibility of Out-of-Court Statements Under the Rules of Evidence ................ 9

A. When Hearsay is Offered, Any Hearsay Exception That Fits Will Work .... 9

B. Judge's Determination of Admissibility ........................................... 10

C. Is Competency of the Out-of-Court Declarant at the

Time of Trial Required? ................................................................ 10

IV. Crawford's Reframing of the Confrontation Clause Analysis ............................. 12

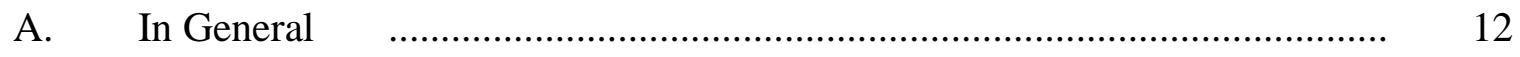

B. In Determining Whether a Statement is Testimonial, Does

It Matter that the Declarant Was a Child? 
C. What Did Crawford and Davis Hold as to Whether a Statement

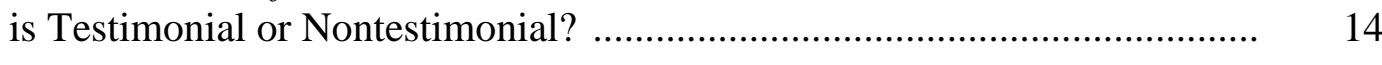

D. What of Statements Not Made During Interrogation by the Police or an Agent of the Police?.............................................................................. 18

1. Elicitation by Police or Their Agents ……………………………..... 18

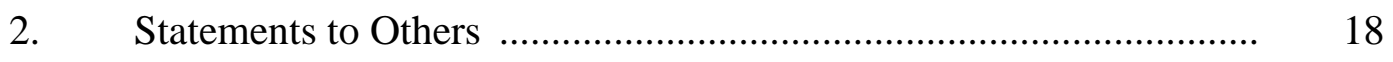

3. Less Formal, More Spontaneous Statements ................................... 19

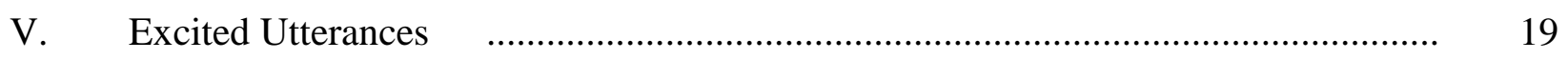

A. $\quad$ Are Excited Utterances Testimonial? ....................................................... 19

1. Crawford Cast Doubt on White v. Illinois ……………………........ 19

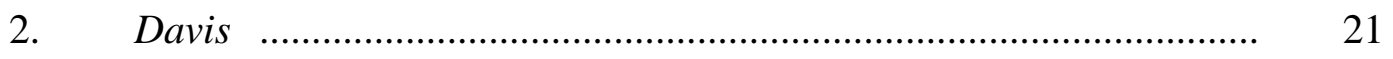

3. Excited Utterances to Persons Not Law Enforcement Agents .......... 21

B. Application of Md. Rule 5-803(b)(2) in the Context of Child Declarants .... 22

VI. Statements Made in Seeking Medical Diagnosis or Treatment ………………........ 23

A. Qualifying Statements under the Hearsay Exception of

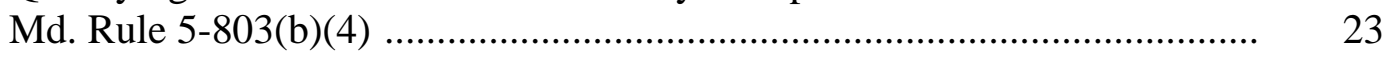

1. Declarant's Motive: Requisite Understanding

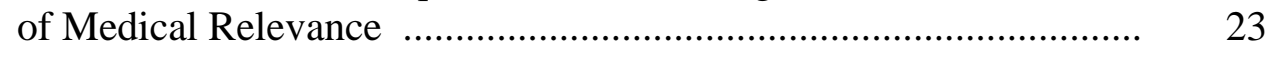

2. Statements Must Be "Reasonably Pertinent to Diagnosis or Treatment" ………………………………................ 24

B. Are Md. Rule 803(b)(4) Statements "Testimonial”? ................................... 26

1. Police Involvement Present or Inferrable ……………………......... 27

2. No Police Involvement ……………………................................. 27

3. Effect of Child Abuse Reporting Requirement ………………….... 28

VII. "Tender Years" and "Catch-All" Exceptions …………............................................ 29 
VIII. Admissibility of Prior Consistent Statements When Child Testifies; State

Law Hearsay Exception for Prompt Complaints of Sexual Assault

IX. Maryland's Hearsay Exceptions Derived from Fed. R. Evid. 804(b)(6):

A Criminal Statute and a Civil Rule

A. The Criminal Statute

1. Restrictive in Scope: Types of Cases

2. Departure from Usual Procedure under Md. Rule 5-104(a)

3. Restrictive in Scope: Types of Out-of-Court Statements

4. Notice

B. The Civil Rule

X. Other Significant Developments

A. Melendez-Diaz

B. Rule 5-802.1(a): Certain Prior Inconsistent Statements

C. Rule 5-802.1(c): Prior Statements of Identification

D. Rule 5-803(a): Statement of Party Opponent

E. Rule 5-803(b)(3): Direct Assertion of Declarant's State of Mind

F. $\quad$ Rule 5-803(b)(6): Business Records

G. Rule 5-803(b)(8): Public Records/"Business Records" of the State?

H. Rule 5-804(b)(2): Dying Declarations

I. Rule 5-805: Multiple Levels of OCS's Within One OCS

J. Doctor's Apology

K. Impeachment of Nontestifying Hearsay Declarants: Md. Rule 5-806.

XI. Hypotheticals

XII. Appendix: Fact Patterns 


\section{Framework for Analysis of Whether an Out-of-Court Statement is Admissible}

To determine whether evidence of an out-of-court statement is admissible, one must make several determinations. If the evidence passes muster under the rules of evidence, then one must ask if its admission would violate the Constitution:

(1) Is the proffered evidence "hearsay" (as defined in Md. Rule 5-801(a)(c))? If the evidence is nonhearsay, neither the hearsay rule nor the Confrontation Clause will exclude it.

If it is hearsay, is it nonetheless not excluded by the hearsay rule, because it qualifies under an exception to that rule (Md. Rule 5-803804)?

(3) Even if the hearsay rule does not exclude it, do other evidence rules exclude it (e.g., Md. Rule 5-403)?

If rules of evidence do not exclude it, then one must ask whether the Constitution bars its consideration.

If it is offered at a trial on the merits ${ }^{1}$ against a criminal accused, is it "testimonial" hearsay? If it is testimonial, then its admission must comply with the confrontation clause.

Even if the confrontation clause is inapplicable, but the evidence is offered in any proceeding to which the due process clause applies, is the evidence reliable? See, e.g., Cotto v. Herbert, 331 F.3d 217 (2d Cir. 2003) (a verdict based on unreliable evidence violates the losing party's due process right).

\section{Is The Evidence Hearsay?}

\section{A. What is Hearsay?}

Evidence is hearsay if (1) an out-of-court statement (any time other than from this witness stand at this trial) of a person (including a hearsay declarant who is also testifying at trial) ("OCS") is being proved, and (2) in order for that OCS to help to prove the fact it is being offered to prove today at trial, the fact-finder would have to assume that the out-ofcourt speaker or writer (the "declarant") believed a particular fact to be true and that the declarant was correct, i.e., that fact was true. The shorthand for this last element is that the OCS is offered now to prove the truth of some matter that was (explicitly or implicitly) asserted by the declarant when the declarant made the statement ("TOMA"): OCS + TOMA = Hearsay.

1 See, e.g., Kentucky v. Stincer, 482 U.S. 730, 740 (1987) (defendant's exclusion from incompetency hearing in judge's chambers regarding child witnesses' competency after jury was sworn did not violate his confrontation right as it did not impinge upon his ability to cross-examine them at trial on the merits). 


\section{The Two Elements of "Out-of-Court" "Statement"}

Rule 5-801(c) defines OCS as "a statement, other than one made by the declarant while testifying at the trial or hearing. ..." Rule 5-801(a) defines a "statement" as "(1) an oral or written assertion or (2) nonverbal conduct of a person, if it is intended by the person as an assertion." It can be fairly said, then, that a "statement" is an assertion of fact(s) by a person.

Because of the first part of the definition in Rule 5-801(c), for purposes of the rules of evidence even the prior statement of a witness who is testifying today at trial is considered an OCS. Thus the hearsay rule excludes a witness's own prior statements unless either (1) they are offered only for a relevant nonhearsay purpose or (2) the proper foundation has been laid to support a finding by the trial judge that they fall within a particular hearsay exception (or exceptions). This may be surprising, because, after all, this witness declarant can be crossexamined at trial. Thus, this preference for live memory is reflected only in a rule of evidence, and not in the confrontation clause.

\section{Problems.}

\section{Does "statement" in Rule 5-801(a) include:}

a. A parrot's exclamation, when the police entered the apartment to find the dead body of Jennifer, the owner of the parrot, "Richard stabbed me! Richard stabbed me!"

b. $\quad$ A hand-stamped "Received April 12, 2003" on a document?

c. A gas and electric bill, stating that the homeowner owed $\$ 310.06$ for July 2007 ?

d. Does "statement" include the mass-printed writing on a cocktail napkin, "Bohager's, Fells Point, Baltimore"?

In each case, whom would you want to cross examine? In United States v. Washington, 498 F.3d 225 (4th Cir. 2007), cert. denied, 129 S.Ct. 2856 (2009), Judge Niemeyer, writing for the panel majority over Judge Michael's dissent, held that data generated by an Armed Forces Institute's Forensic Toxicology Laboratory, showing that the defendant's blood sample contained ethanol and phencyclidine, were not hearsay, because the machine performing chromatography on the defendant's blood was not a "person" and therefore could not be a "declarant" under Fed. R. Evid. 801. ${ }^{2}$ Accord United States v. Moon, 512 F.3d 359, 361-62 (7th Cir. 2008) (instruments'

2 The lab in Washington used:

a Hewlett Packard HP 6890 series gas chromatograph machine and computers with HP ChemStation software. After lab technicians subjected the blood sample to testing, the instruments printed out some 20 pages of data and graphs. Based on the data, the director of the lab and its chief toxicologist, Dr. Barry Levine, issued a report to the United States Park Police, stating that the blood sample "contained $27 \mathrm{mg} / \mathrm{dL}$ 
readings were not statements, though expert's conclusions based on them were), cert. denied, 129 S.Ct. 40 (U.S. 2008), and cert. denied sub nom. Alexander v. United States, 129 S.Ct. 39 (U.S. 2008). The facts of Melendez-Diaz v. Massachusetts, 129 S.Ct. 2527 (2009), do not raise this question, because there the evidence was not a machine printout but a drug analysis certificate by a person, based on the machine readings (and the evidence was admitted without the testimony of any sponsoring witness).

It is noteworthy, and perhaps critical, that in United States $v$. Washington no issue as to authentication or chain of custody was presented or preserved.

\section{2. $\quad$ Making and Meeting Hearsay Objections}

a. If a hearsay objection is properly made because the evidence includes an OCS, the proponent of the evidence must meet the objection by explaining to the court how either the evidence is nonhearsay or it falls within a hearsay exception. Otherwise, the court may correctly sustain the objection.

b. Timeliness. One can object in anticipation - but the objection is not technically called for until the hearsay itself is asked for.

\section{3. "TOMA"? or Nonhearsay?}

Remember, an OCS is not hearsay if it is probative of and offered to prove a RELEVANT fact other than "TOMA" (the truth of any fact asserted by the declarant when the declarant made the OCS). All evidence must comply with Rule 5-402, requiring relevance. Offering evidence for a nonhearsay purpose that is not relevant will not provide a route around the hearsay rule. E.g., Boyd v. State, 399 Md. 457, 924 A.2d 1112 (2007).

An easy way to look at the TOMA element is to ask, "Even if the out-of-court declarant was factually incorrect with regard to the assertion s/he made in the OCS, is it still relevant that the declarant made the statement?" "Is it relevant simply that the OCS was made?" If the answer to either of these questions is yes, the evidence is NONHEARSAY. (A limiting instruction under Rule 5-105 may be appropriate.)

of ethanol" and that the sample tested positive for phencyclidine, containing " $0.04 \mathrm{mg}$.L of phencyclidine as quantitated by gas chromatography/spectrometry." While Dr. Levine did not see the blood sample and did not conduct any of the tests himself, three lab technicians operating under his protocols and supervision conducted the tests and then presented the raw data from the tests to him.

The raw data were mechanical computer printouts with each page headed by the date of the test, the machine operator, an identification of the sample, its dilution factor, and other similar information, and containing computer-generated graphs and data reporting the results produced by the chromatograph machine.

498 F.3d at 728. 
Another way of looking at this process is as a bus ride; you jump off the bus as soon as you get some probative value as to the fact the OCS is offered to prove.

\begin{tabular}{|l|l|l|}
\hline \multicolumn{1}{|c|}{ Metrobus } & \multicolumn{1}{|c|}{ Metrobus } & \multicolumn{1}{c|}{ Metrobus } \\
If it doesn't matter whether Decl. \\
believed what s/he said or not, \\
$\begin{array}{l}\text { EVI. is probative anyway, will help to prove fact it's } \\
\text { merely because OCS was made: } \\
\text { offered to prove, as long as Decl. } \\
\text { believed what s/he said, even if } \\
\text { Decl. was factually wrong. }\end{array}$ & $\begin{array}{l}\text { If Decl.'s belief alone is } \\
\text { insufficient: we need for Decl. } \\
\text { to have been both sincere and } \\
\text { factually correct, in order for } \\
\text { fact-finder to properly rely on } \\
\text { the Evi. to help to prove the } \\
\text { Material Fact. }\end{array}$ \\
$\begin{array}{l}\text { Get off at } \\
\text { BUS STOP \#1: Nonhearsay } \\
\text { (Types a, b, or c below) }\end{array}$ & $\begin{array}{l}\text { Get off at } \\
\text { BUS STOP \# 2: Nonhearsay } \\
\text { (Type d below) }\end{array}$ & $\begin{array}{l}\text { Ride all the way to } \\
\text { TERMINUS: Hearsay }\end{array}$ \\
\hline
\end{tabular}

\section{Problems.}

Witness is called to testify: "The shopkeeper told me one of the people who robbed her was Wally." Is this evidence hearsay (an OCS + TOMA) if it is offered to prove the following?

1. Wally robbed the shopkeeper.

2. The witness knows the shopkeeper.

3. The shopkeeper was alive on the day she spoke to the witness.

4. Wally is a criminal.

5. The shopkeeper and the witness were "on speaking terms."

6. Wally was in the town where the shop is on the day of the robbery.

Analysis: For example, would the fact that the shopkeeper said to the witness, that "Wally was one of the robbers" help to prove that Wally was in that town on the day of the robbery only if the shopkeeper was factually correct about one or more of the facts she asserted in the OCS?

Four categories of OCS's that are NONHEARSAY because they are offered for a purpose other than to prove TOMA [both belief and accuracy of the declarant as to something s/he was asserting at the time the declarant made the OCS] come up repeatedly:

a. "LEGALLY OPERATIVE FACTS" (Verbal acts or Verbal Parts of Acts) 
i. VERBAL ACTS (here, generally, the substantive law regarding the particular type of claim or defense requires that an out-of-court statement have been made in order for the type of claim, charge, or defense to exist), e.g., contracts; wills; the alleged defamatory statement. You cannot have a contract, for example, without an offer and an acceptance. The utterance of the statement(s) creates the claim, etc.

Example: Mario sues D for slander. Mario calls W to testify that D said to W, "Mario is a liar and a cheat." Mario simply wants to prove that D made the OCS (published it to a third person) - certainly not to prove that what $\mathrm{D}$ said was true. $\mathrm{D}$ has to have made such a type of statement in order for Mario to prove the element of publication.

ii. VERBAL PARTS OF ACTS (giving a particular legal effect, by virtue of the substantive law, to an otherwise legally ambiguous nonverbal act). These OCS's have probative value under the substantive law, regardless of the declarant's sincerity (truthfulness). For example, the statement, "This is a gift," when handing over a ring, makes it a donative transfer, even if the declarant was intending to steal the ring back later. Similarly, a threatening statement accompanying an otherwise ambiguous act can make the combination an assault.

\section{b. STATEMENTS OFFERED TO PROVE THEIR EFFECT ON THEIR HEARER OR READER}

These statements, e.g., statements putting the hearer or reader on notice ("Caution: Wet Floor") or statements affecting the reasonableness of the hearer's or reader's subsequent conduct ("Don't touch that, it's hot!") are probative for that purpose, regardless of either the declarant's sincerity or accuracy.

- If A testifies that she heard B tell the store manager, 15 minutes before a slip and fall, that "There's a spill in Aisle 6," can this evidence be relevant for a nonhearsay purpose? How? Note that, if offered for a nonhearsay purpose, it may not be used as substantive evidence that there was a spill in Aisle 6. A limiting instruction under Rule 5-105 may be requested.

See, e.g., Shipp v. United States, 212 Fed. Appx. 393 (6th Cir. 2006) (unpublished) (malicious prosecution case).

c. STATEMENTS OFFERED AS CIRCUMSTANTIAL 

ABILITY TO TALK, ABILITY TO SPEAK A PARTICULAR LANGUAGE, ETC.

- Neither sincere belief nor accuracy of the declarant is needed for this category of non-hearsay. For example, consider the statement of a person (not the Prince of Wales) trapped in a car, "I am Charles, Prince of Wales," offered to show consciousness, which is relevant to conscious pain and suffering, which is relevant to damages. It does not matter whether what the declarant said was true, simply that she said something.

d. STATEMENTS OFFERED AS CIRCUMSTANTIAL -- NOT DIRECT -- EVIDENCE OF THE DECLARANT'S EMOTION, STATE OF MIND, KNOWLEDGE, BELIEF, INTENT, SANITY OR INSANITY

In this final one of the "big four" categories of nonhearsay, the relevance requirement is met if the declarant was sincere, regardless of the declarant's accuracy as to the facts asserted by him or her. E.g., in A's trial for murder of B, the State calls C to testify to A's OCS one week before the murder, "B is not only mean and nasty, he's an [expletive deleted]." To be relevant to the State's case, it does not matter whether B was really mean, nasty, etc. Therefore, it is nonhearsay, as we care only that apparently A believed that B was nasty, not whether A was correct as to the fact A asserted, that B was nasty.

See, e.g., Thomas v. State, 397 Md. 557, 575-80, 919 A.2d 49 (2007) (evidence of defendant's initial refusal to provide a blood sample was properly admitted as circumstantial evidence of consciousness of guilt as State had laid proper foundation by showing that defendant was told blood was needed in reference to victim's death); Holland v. State, $122 \mathrm{Md}$. App. 532, 713 A.2d 364 (1998) (witness testified defendant or one of his companions in motel room said "We're going down the strip to sell"; Judge Moylan explains: "The words were offered as circumstantial evidence that either the appellant or the other codefendant who uttered them along with others who heard the words were privy to a concerted plan to sell narcotics-on the strip or elsewhere, immediately or after the coast was clear. The very uttering of the words helped to show the state of mind of the one who uttered them and/or of others who heard them. As circumstantial evidence used to prove that collective state of mind, to wit, the [charged] conspiracy [to sell illegal drugs], the words were non-hearsay.").

\section{4. $\quad$ Important Recent Maryland Decisions: Implied Assertions}

The common law rule of Wright v. Tatham, an 18th century English case, as to verbal utterances may be stated as follows:

Verbal utterances are hearsay if offered to prove the truth of the matter that was directly asserted by the declarant. They are also hearsay if they are offered to prove the truth of an assertion implied by the declarant, i.e., their proponent is 


\section{asking the fact-finder to infer that the declarant would not have made the utterance unless he or she believed a particular fact to be true, and the out-of-court utterance is offered to prove the truth of that fact the declarant apparently believed.}

In Stoddard v. State, 389 Md. 681, 887 A.2d 564 (2005), the Court of Appeals of Maryland (4to-3) adopted this approach. There the OCS was of an 18-month-old child who said to her mother, "Is [the defendant] going to get me?" The evidence was relevant only if offered to prove that the child had seen the defendant "get" the murder victim.

Under this approach, each of the following is an OCS + TOMA:

\section{$\underline{\text { Evidence }}$}

a. D said, "Do you need change?"

b. D said, "Carlos, do you have the stuff?"

c. D, a burglar, said, "Ernie, come in here."

d. D said to X, "You wouldn't want anything to happen to your pretty wife."

e. $\quad$ D asked $\mathrm{X}$, "When are you going to pay me back my money?"

f. D said to $\mathrm{X}$, his alleged coconspirator, "Nice to meet you."

\section{Offered to Prove}

D had access to change.

Carlos dealt drugs.

Ernie was there and was D's accomplice.

D was threatening $X$.

$\mathrm{X}$ had borrowed money from D.

$\mathrm{D}$ had never met $\mathrm{X}$ before.

Contrast:

\section{$\underline{\text { Evidence }}$}

D said, "Does your boss have a burglar alarm?"

\section{Offered to Prove}

D was planning a burglary of the premises and committed it and accompanying murder of the store owner.

Here D's intent is relevant. The evidence is relevant in D's subsequent burglary/murder trial as circumstantial evidence of D's state of mind/intent; one "gets off the bus" before reaching any implicit assertion about whether or not there is a burglar alarm. See Carlton v. State, 111 Md. App. 436, 681 A.2d 1181 (1996) (finding no intended assertion).

In Bernadyn v. State, 390 Md. 1, 887 A.2d 602 (2005), the Stoddard majority held that a medical bill seized by police at 2024 Morgan Street in Edgewood, Maryland, and addressed to 
"Michael Bernadyn, 2024 Morgan Street, Edgewood, Maryland 21040," was inadmissible hearsay when used by the State to establish that Bernadyn lived at that address.

- When that scenario recurs, can the foundation for the bill as a business record be laid as to the patient's address? Is there a double hearsay problem?

- Or is the bill with that name on it relevant (does it have probative value connecting Bernadyn to that address) simply because it was found at that address? (See Judge Wilner's dissent.) Consider if, instead, the bill had been found at a garbage dump - then what would the analysis be?

- If the State offers the bill, at retrial, only as circumstantial evidence linking someone using that name with the address where it was found, will it be admissible for that limited purpose? See Fields v. State, 395 Md. 758, 912 A.2d 637 (2006) (declining to reach the issue because error, if any, was harmless) (see also D. Eyler's opinion for majority of the CSA panel, 168 Md. App. 22, 895 A.2d 339 (2006)); Cooley v. State, 157 Md. App. 101, 116, 849 A.2d 1026 (2004), rev'd on other grounds, 385 Md. 165, 867 A.2d 1065 (2005) ("The State's case included testimony that, when the search warrant was executed about 6:20 a.m. on July 20, 2001, both Jones and Cooley were present, along with their child. Cooley was sleeping when the police arrived. Both Cooley and Jones were in the bedroom at the time the bullet cartridges were recovered. In addition, paperwork in the names of both Jones and Cooley was recovered from the premises. This evidence was sufficient to establish that Cooley and Jones were residing together at $2001 \mathrm{McCullough}$ Street when the search warrant was executed.").

How far will the Court of Appeals take Stoddard? Watch Garner v. State, 183 Md. App. 122, 960 A.2d 649 (2008) (telephone caller's question, “Can I get a 40?” is nonhearsay), cert. granted, 408 Md. 148, 968 A.2d 1064 (2009). See MCLAIn, 6A MARYLAND EvidEnCE $§$ 801:4 (Supp. 2009).

B. Evidence Offered for a Nonhearsay Purpose is Not Subject to the $\underline{\text { Confrontation Clause }}$

The United States Supreme Court has stated that the confrontation right applies only to hearsay. Crawford v. Washington, 541 U.S. 36, 59 n.9 (2004) ("The Clause . . does not bar the use of testimonial statements for purposes other than establishing the truth of the matter asserted."); Tennessee v. Street, 471 U.S. 409 (1985) (defendant's rights under the confrontation clause were not violated by the introduction of the confession of an accomplice for the nonhearsay purpose of rebutting respondent's testimony that his own confession was coercively derived from the accomplice's statement).

The confrontation clause would not bar the admission, for example, of a nontestifying hearsay declarant's prior consistent testimonial statements, when offered as to her credibility only, to rehabilitate her after she has been impeached pursuant to Md. Rule 5-806. Cf. Holmes $v$. State, 350 Md. 412, 712 A.2d 554 (1998) (discussing admissibility of prior consistent statements as to rehabilitation of a testifying witness); United States v. Lechoco, 542 F.2d 84, 89 n.6 (D.C. 
Cir. 1976) (prosecution's attack on credibility of defendant, on whose out-of-court statements defense psychiatrists relied, permits defendant to present supporting evidence, as by character witnesses to his good reputation for truth and veracity). A Md. Rule 5-403 question of whether a Md. Rule 5-105 limiting instruction would be effective would remain, however.

Similarly, Md. Rule 5-703 permits the opinion of a testifying expert to be based on inadmissible hearsay. But an expert's reliance on testimonial hearsay of nontestifying declarants raises thorny questions. See United States v. Crockett, 586 F.Supp.2d 877 (E.D. Mich. 2008) (prosecution expert may not testify to whether laboratory results showed cocaine, without admissible evidence of chain of custody; "Rule 703 [cannot] be understood to contemplate the very judicial balancing that Crawford eschews"); Comment, Crawford's Curious Dictum: Why Testimonial "Nonhearsay" Implicates the Confrontation Clause, 82 TUL. L. REV. 297 (2007). But see United States v. Law, 528 F.3d 888, 911-12 (D.C. Cir. 2008) (no violation of confrontation right when prosecution expert relied on testimonial hearsay but did not disclose it to jury), cert. denied sub nom. Fletcher v. United States, 129 S.Ct. 1023 (U.S. Jan. 21, 2009); United States v. Lombardozzi, 491 F.3d 61 (2d Cir. 2007) (some of prosecution expert's opinions were based on admissible evidence; admission of other, even if based on testimonial hearsay, was not plain error where, inter alia, it did not concern a crime for which defendant was on trial).

\section{Admissibility of Out-of-Court Statements Under the Rules of Evidence}

\section{A. When Hearsay is Offered, Any Hearsay Exception That Fits Will Work}

The rules of evidence recognize many hearsay exceptions potentially applicable to, for example, children's out-of-court statements. Hearsay exceptions of particular interest with regard to child declarants include:

1. Excited utterances: Md. Rule 5-803(b)(2); White v. Illinois, 502 U.S. 346 (1992); see Davis v. Washington, 547 U.S. 813 (2006);

2. Statements made when seeking medical diagnosis or treatment: Md. Rule 5-803(b)(4); White v. Illinois, 502 U.S. 346 (1992);

3. "Tender years" exceptions, e.g., Snowden v. State, 385 Md. 64, 867 A.2d 314 (2005);

4. Catch-all or residual exceptions, Md. Rule 5-803(b)(24); see Idaho v. Wright, 497 U.S. 809 (1990);

5. The forfeiture-by-wrongdoing exception: Md. Rule 5-804(b)(5) (civil); Md. Cts. \& Jud. Proc. Code Ann. § 10-901 (certain criminal cases only); see, e.g., McMenamin, Man Charged in Death of Woodlawn Girl Is Expected to Plead Guilty, The Balt. Sun, May 10, 2005, at 5B, col. 1 (15year-old girl murdered to keep her from testifying in a third degree sex offense case); McMenamin, Murder Trial Pierces Calm of Quiet City in New York, The Balt. Sun, Sept. 17, 2004, 1B, col. 1 (Randallstown, MD 
man charged with murdering 14-year-old girl and her mother, ten days before they were to testify in sexual abuse trial in Maryland).

\section{B. Judge's Determination of Admissibility}

When a hearsay objection is made and the proponent of the evidence argues that it falls within a hearsay exception, the trial judge decides the issue of admissibility under Md. Rule 5104(a). The judge may admit the evidence only if he or she finds that the preliminary facts necessary to lay the required foundation have been proven by a preponderance of the evidence. Daubert v. Merrill Dow Pharms., Inc., 509 U.S. 529, 592 \& n.10 (1993).

The judge nevertheless should exclude the evidence, upon objection, if other evidentiary rules so require, for example, if the declarant appears to have lacked first-hand knowledge (Md. Rule 5-602; Brown v. Keane, 355 F.3d 82 (2d Cir. 2004)) or if the probative value of the evidence is substantially outweighed by the risk of unfair prejudice, confusion of the jury, or undue consumption of time (Md. Rule 5-403; United Fire \& Cas. Co. v. Historic Preservation Trust, 265 F.3d 722, 727-28 (8th Cir. 2001); United States v. Dhinsa, 243 F.3d 635, 655-56 (2d Cir. 2001)).

In making these preliminary determinations as to admissibility, the court may consider hearsay; it is not bound by the rules of evidence, except those regarding privileges and competency of witnesses. E.g., Bourjaily v. United States, 483 U.S. 171 (1987); United States v. Haldeman, 559 F.2d 31, 107 (D.C. Cir. 1976).

\section{Is Competency of the Out-of-Court Declarant at the Time of Trial Required?}

With regard to the admission of hearsay, the preliminary question as to competency is not whether the declarant is competent to testify at the time of trial. The touchstone instead is whether the declarant, when he or she made the out-of-court statement, appears to have been capable of perceiving facts accurately and relating them rationally. See, e.g., Contee v. State, 184 A.2d 823, 825-26 (Md. 1962) (prior testimony admissible of declarant who had subsequently become insane). But see Myrna S. Raeder, Comments on Child Abuse Litigation in a "Testimonial" World: The Intersection of Competency, Hearsay, and Confrontation, 82 Ind. L.J. 1009, 1011-12 (2007) (accepting the rule of King v. Brasier, 168 Eng. Rep. 202 (K.B. 1779), as "confirm[ing] that an incompetent child's hearsay cannot be introduced because the child could not be a witness at trial," and treating excited utterances as sui generis because their reliability is not premised on child's ability to discern truth from a lie); Stoddard v. State, 389 Md. 681, 715-16, 742-44 (Wilner J., concurring, joined by Battaglia and Greene, JJ.) (expressing view similar to Prof. Raeder's: "outside the realm of excited or spontaneous utterances or statutory admissibility," hearsay is inadmissible if the declarant - here an 18-month-old child would have been incompetent to testify).

The trial court in Idaho v. Wright, 497 U.S. 805, 825 (1990), "implicitly" had found the young out-of-court declarant, "at the time she made the statements, . . . capable of receiving just impressions of the facts and of relating them truly." The United States Supreme Court held: 
[T]he Confrontation Clause does not erect a per se rule banning the admission of prior statements of a declarant who is unable to communicate to the jury at the time of trial. Although such inability might be relevant to whether the earlier hearsay statement possessed particularized guarantees of trustworthiness, a per se rule of exclusion would not only frustrate the truth-seeking purpose of the Confrontation Clause, but would also hinder States in their own "enlightened development in the law of evidence."

Id. (citations omitted). See Swan v. Peterson, 6 F.3d 1373, 1381-82 (9th Cir. 1993) (state court committed no error in admitting, under tender years exception, out-of-court statement of young child who was incompetent to testify at trial); Morgan v. Foretich, 846 F.2d 941, 945-48 (4th Cir. 1988) (excited utterances by alleged child sexual abuse victim to her mother were admissible, regardless whether child was competent to testify at trial); Myatt v. Hannigan, 910 F.2d 680 (10th Cir. 1990) (Kansas statute did not violate confrontation clause, nor did admission of "unqualified" child's reliable out-of-court statements to social worker and police officer; psychiatrist had testified that child knew difference between right and wrong and that his statements were reliable); People v. District Court of El Paso County, 776 P.2d 1083, 1087 (Colo. 1989); Perez v. State, 536 So.2d 206, 211 (Fla. 1989); People v. Rocha, 547 N.E.2d 1335, 1341 (Ill.Ct.App. 1989); Miller v. State, 517 N.E.2d 64, 72 n.7 (Ind. 1987); State v. Bobadilla, 709 N.W.2d 243, 248, 256 (Minn. 2006), cert. denied, 549 U.S. 943 (2006) (child does not have to be competent to testify at trial in order for his statement to be admitted under the Minnesota "tender years" hearsay exception), habeas corpus granted on other ground, 570 F.Supp.2d 1098 (D. Minn. 2008); State v. Campbell, 705 P.2d 694, 703-06 (Or. 1985) (if trial court holds competency hearing and finds alleged victim of child abuse incompetent to testify, child's outof-court statements may be admitted under hearsay exception for complaints of sexual misconduct); State v. C.J., 63 P.2d 765 (Wash. 2003) (statement admissible under tender years statute); State v. Fisher, 108 P.3d 1262 (Wash.App. 2005), review denied, 132 P.2d 147 (Wash. 2006); Jon R. Waltz, The Present Sense Impression Exception to the Rule Against Hearsay: Origins and Attributes, 66 IowA L. REV. 869, 879 (1981).

This result takes into account principles of developmental psychology. A child of a certain age may be able to accurately relate very recent events but not events of a long time ago. (An Alzheimer's patient might have the opposite capacity.) Excited utterances of young children have often been admitted, though the children would not have been permitted to testify in court. E.g., State v. Giles, 772 P.2d 191 (Idaho 1989); Moore v. State, 26 Md. App. 556, 561, 338 A.2d 344,347 (1975) (excited utterance of 3-1/2-year-old child was admissible; child's competence is "irrelevant since the testimonial qualifications do not apply to spontaneous declarations").

If, however, the statement was made by a person who is shown to have lacked sufficient mental capacity to have made any rational statement at the time the statement was made, the court should exclude the statement. See United States v. Barrett, 8 F.3d 1296, 1300 (8th Cir. 1993) ("Another factor to consider in determining whether [the child victim's] hearsay statements contain particularized guarantees of trustworthiness is the reason for [the child's] inability to testify at trial. While the Confrontation Clause 'does not erect a per se rule barring the admission of prior statements of a declarant who is unable to communicate to the jury at the time of trial,' the declarant's inability to communicate may be relevant to whether the hearsay 
statements possessed particularized guarantees of trustworthiness. Should the district court determine that [the child] did not know the difference between the truth and a lie, this finding would have an obvious impact on whether [her] hearsay statements were trustworthy."); Ring $v$. Erickson, 983 F.2d 818 (8th Cir. 1992) (admission of videotaped interviews of 3-year-old child victim, whom state court determined to be incompetent to testify at trial, not shown to have adequate indicia of reliability, was violation of accused's confrontation right and reversible error); Hutchcraft v. Roberts, 809 F. Supp. 846 (D. Kan. 1992) (state court violated defendant's confrontation rights by admitting out-of-court statements of mentally retarded teenaged victim when, inter alia, preliminary hearing judge found declarant unavailable to testify on ground that she could not discern the truth from falsehood); State v. Karpenski, 971 P.2d 553 (Wash. App. Div. 2 1999) (child victim was neither competent to testify at trial nor competent when he made numerous inconsistent and fantastic out-of-court statements; reversible error to permit child to testify and to admit his out-of-court statements). See also Miller v. State, 531 N.E.2d 466 (Ind. 1988) (under all circumstances, including use of leading questions, reversible error to admit unreliable statement).

\section{Crawford's Reframing of the Confrontation Clause Analysis}

\section{A. In General}

Crawford v. Washington, 541 U.S. 36 (2004), and Davis v. Washington, 547 U.S. 813 (2006), establish that the confrontation clause applies only to "testimonial" hearsay offered by the prosecution. Such evidence may be received only under one of three scenarios: ${ }^{3}$ either

1. The accused has forfeited his or her confrontation right by engaging in wrongdoing (directly or in a conspiracy) that was intended to and did cause the declarant to be unavailable to testify (proof of the wrongdoing may be difficult to achieve without the cooperation of an intimidated witness, however); see Giles v. California, 128 S.Ct. 2678 (U.S. 2008); or

2. The declarant is unavailable to testify at trial (see Md. Rule 5-804(a)) and the accused has earlier (e.g., at a preliminary hearing) had an opportunity to cross-examine the declarant about his or her statement that is now being offered into evidence; or

3. The out-of-court declarant who made the testimonial hearsay statement testifies at the trial, so that the accused has an opportunity to cross-examine the declarant at trial, Crawford, 541 U.S. at 59 n.9; Lawson v. State, 389 Md. 570, 587-89, 886 A.2d 876 (2005).

If a statement helpful to the prosecution is "testimonial," and neither of the first two scenarios has been met, Crawford and Davis maximize the prosecution's incentives to do

3 Crawford suggests, however, that even testimonial dying declarations may not be excluded by the confrontation clause, because they were admissible under the common law of 1791. 541 U.S. at 56 n.6. 
everything possible to have the declarant testify at trial. There are, however, practical impediments to achieving this goal:

1. Child abuse victims who are very young may be found to be unqualified to testify at trial;

2. Parents or guardians may not wish to permit the prosecution to expose children to the stress of trial;

3. Child or adult witnesses may be unwilling to testify, for fear of retaliation; and

4. Some domestic violence victims may be entitled to invoke a marital privilege not to testify. ${ }^{4}$

If the hearsay statement is "nontestimonial," the confrontation clause does not apply to its admission. Davis v. Washington. The only constitutional check will be the due process clause, under which a verdict that was based on unreliable hearsay would be constitutionally unsound. As to what is "reliable" we can still look to Ohio v. Roberts, 448 U.S. 56 (1980), for this due process purpose.

B. In Determining Whether a Statement is Testimonial, Does It Matter that the Declarant Was a Child?

Although this particular argument of his has not yet gained traction with the courts, Professor Richard Friedman has argued that "very young children" are too young "to be deemed a witness" within the meaning of the confrontation clause, whether because of "cognitive" reasons or because incapable of understanding "making a choice to testify," and their out-of-court utterances should be admitted "for what they are worth, without pretending that the children have the capacity to act like adults." Richard D. Friedman, The Conundrum of Children, Confrontation, and Hearsay, 65 L. \& CONTEMP. PROBS. 243, 251-52 \& n.4 (No. 1, Winter 2002). Thus, he concludes that statements by an eighteen-month-old and a two-and-a-half-year-old would probably not be testimonial. Id. at 249 .

But in Crawford and Davis, Justice Scalia repeatedly asserts that the test for "testimony" turns on what an "objective" declarant would think. ${ }^{5}$ Crawford, 541 U.S. at 52; Davis, 547 U.S. $813,822,826,827,828,830$ \& n.5 (2006). His "objective" test does not seem to leave room for the lower courts to focus on the declarant's youth. In Snowden v. State, 385 Md. 64, 90-91, 867 A.2d 314, 329 (2005), the court adopted the view that the operable test was one "using an objective person, rather than an objective child of that age." Accord State v. Henderson, 129

4 Such a refusal is likely to adversely affect children of the marriage, as "domestic violence and child mistreatment, problems are often intertwined. ..." Note, Caught between a Rock and a Hard Place: Harmonizing Victim Confidentiality Rights with Children's Best Interests, 70 Mo. L. REv. 863, 863 (2005).

5 Justice Scalia's dictum regarding White v. Illinois supports this conclusion. See text following note 6 infra. 
P.3d 646 (Kan. App. 2006), aff'd, 165 P.3d 776 (Kan. 2007). Contra People v. Stechly, 879 N.E.2d 333, 366 (Ill. 2007) (plurality decision) (age of child declarant is one factor to consider with regard to whether her statement to her mother on way to hospital was testimonial).

\section{What Did Crawford and Davis Hold as to Whether a Statement is Testimonial or Nontestimonial?}

Crawford finds the Sixth Amendment unclear on its face and therefore looks to the founders' intent when the Amendment was ratified in 1791. Justice Scalia, writing for the Court, concludes that the founders were concerned that we not repeat a practice that had occurred during "Bloody Mary's" reign in England where - following the civil law practice rather than the common law's approach - justices of the peace gathered ex parte statements from witnesses and later these were offered into evidence at some trials, without the accused being given a chance to cross-examine the makers of the statements.

Justice Scalia remarks, "The involvement of government officers in the production of testimonial evidence presents the same risk, whether the officers are police or justices of the peace." He reasons that "witnesses are those who bear testimony," but declines to articulate a definition of "testimonial." Crawford explicitly states that the following are testimonial under any definition:

(1) "ex parte testimony at a preliminary hearing";

(2) "plea allocution";

(3) "grand jury testimony";

(4) prior trial testimony; and

(5) "[s]tatements taken by police officers in the course of interrogations. ..."6

In Davis, again in an opinion authored by Justice Scalia, the Court holds:

Without attempting to produce an exhaustive classification of all conceivable statements - or even all conceivable statements in response to police interrogation — as either testimonial or nontestimonial, it suffices to decide the

6 The Crawford Court explained in its footnote 4 that it declined to define interrogation:

We use the term "interrogation" in its colloquial, rather than any technical legal, sense. Cf. Rhode Island v. Innis, 446 U.S. 291, 300-301, 100 S.Ct. 1682, 64 L.\$Ed.2d 297 (1980). Just as various definitions of "testimonial" exist, one can imagine various definitions of "interrogation," and we need not select among them in this case. Sylvia's recorded statement, knowingly given in response to structured police questioning, qualifies under any conceivable definition.

In footnote 1 in Davis, the Court qualified its reference to interrogation as follows: "This is not to imply, however, that statements made in the absence of any interrogation are necessarily nontestimonial. The Framers were no more willing to exempt from cross-examination volunteered testimony or answers to open-ended questions than they were to exempt answers to detailed interrogation." 
present cases to hold as follows: Statements are nontestimonial when made in the course of police interrogation under circumstances objectively indicating that the primary purpose of the interrogation is to enable police assistance to meet an ongoing emergency. They are testimonial when the circumstances objectively indicate that there is no such ongoing emergency, and that the primary purpose of the interrogation is to establish or prove past events potentially relevant to later criminal prosecution.

Davis involved two cases. In Davis itself, the Court held that the victim's statements during the beginning moments of a 911 call [e.g., "He's here jumpin' on me again."] were nontestimonial:

The statements in Davis were taken when McCottry was alone, not only unprotected by police, but apparently in immediate danger from Davis. She was seeking aid, not telling a story about the past. McCottry's present-tense statements showed immediacy.

$* * *$

In Davis, McCottry was speaking about events as they were actually happening, rather than "describ[ing] past events." *** Moreover, any reasonable listener would recognize that McCottry ... was facing an ongoing emergency.

Although one might call 911 to provide a narrative report of a crime absent any imminent danger, McCottry's call was plainly a call for help against bona fide physical threat. Third, the nature of what was asked and answered in Davis, again viewed objectively, was such that the elicited statements were necessary to be able to resolve the present emergency, rather than simply to learn (as in Crawford) what had happened in the past. That is true even of the operator's effort to establish the identity of the assailant, so that the dispatched officers might know whether they would be encountering a violent felon. And finally, the difference in the level of formality between the two interviews is striking. Crawford['s wife] was responding calmly, at the station house, to a series of questions, with the officer-interrogator taping and making notes of her answers: McCottry's frantic answers were provided over the phone, in an environment that was not tranquil, or even (as far as any reasonable 911 operator could make out) safe.

We conclude from all this that the circumstances of McCottry's interrogation objectively indicate its primary purpose was to enable police assistance to meet an ongoing emergency. She simply was not acting as a witness; she was not testifying. $* * *$

This is not to say that a conversation which begins as an interrogation to determine the need for emergency assistance cannot, as the Indiana Supreme Court put it, "evolve into testimonial statements," once that purpose has been achieved. In this case, for example, after the operator gained the information needed to address the exigency of the moment, the emergency 
appears to have ended (when Davis drove away from the premises). The operator then told McCottry to be quiet, and proceeded to pose a battery of questions. It could readily be maintained that, from that point on, McCottry's statements were testimonial, not unlike the "structured police questioning" that occurred in Crawford. This presents no great problem. Just as, for Fifth Amendment purposes, "police officers can and will distinguish almost instinctively between questions necessary to secure their own safety or the safety of the public and questions designed solely to elicit testimonial evidence from a suspect," trial courts will recognize the point at which, for Sixth Amendment purposes, statements in response to interrogations become testimonial. Through in limine procedure, they should redact or exclude the portions of any statement that have become testimonial, as they do, for example, with unduly prejudicial portions of otherwise admissible evidence.

On the other hand, it held that in the companion case of Hammon v. Indiana, the domestic violence victim's (1) oral statements to the responding police, in answer to their questions and (2) her affidavit signed at the scene were both testimonial. Justice Scalia analyzed the statements to the responding police as follows:

It is entirely clear from the circumstances [in Hammon] that the interrogation was part of an investigation into possibly criminal past conduct - as, indeed, the testifying officer expressly acknowledged. There was no emergency in progress; the interrogating officer testified that he had heard no arguments or crashing and saw no one throw or break anything. When the officers first arrived, Amy told them that things were fine, and there was no immediate threat to her person. When the officer questioned Amy for the second time, and elicited the challenged statements, he was not seeking to determine (as in Davis) "what is happening," but rather "what happened." Objectively viewed, the primary, if not indeed the sole, purpose of the interrogation was to investigate a possible crime....

7 Justice Thomas roundly criticized the Court for failing to provide a workable standard for distinguishing between testimonial and nontestimonial statements:

In many, if not most, cases where police respond to a report of a crime, whether pursuant to a 911 call from the victim or otherwise, the purposes of an interrogation, viewed from the perspective of the police, are both to respond to the emergency situation and to gather evidence. See New York v. Quarles, 467 U.S. 649, 656 (1984) ("Undoubtedly most police officers [deciding whether to give Miranda warnings in a possible emergency situation] would act out of a host of different, instinctive, and largely unverifiable motives - their own safety, the safety of others, and perhaps as well the desire to obtain incriminating evidence from the suspect"). Assigning one of these two "largely unverifiable motives," primacy requires constructing a hierarchy of purpose that will rarely be present - and is not reliably discernible. It will inevitably be, quite simply, an exercise in fiction. $* * *[\mathrm{~T}]$ he fact that the officer in Hammon was investigating $\mathrm{Mr}$. Hammon's past conduct does not foreclose the possibility that the primary purpose of his inquiry was to assess whether Mr. Hammon constituted a continuing danger to his wife, requiring further police presence or action. It is hardly remarkable that Hammon did not act abusively towards his wife in the presence of the officers, and his good judgment to 
*** It was formal enough that Amy's interrogation was conducted in a separate room, away from her husband (who tried to intervene), with the officer receiving her replies for use in his "investigat[ion]." **** Both declarants [Hammon's wife, Amy, and Crawford's wife, Sylvia] were actively separated from the defendant - officers forcibly prevented Hershel from participating in the interrogation. Both statements deliberately recounted, in response to police questioning, how potentially criminal past events began and progressed. And both took place some time after the events described were over. Such statements under official interrogation are an obvious substitute for live testimony, because they do precisely what a witness does on direct examination; they are inherently testimonial.

$* * *$ Amy's narrative of past events was delivered at some remove in time from the danger she described. And after Amy answered the officers' questions, he had her execute an affidavit, in order, he testified, "[t]o establish events that have occurred previously."

In extending "testimonial" to responses to at least some responses to initial police inquiries in the field, ${ }^{8}$ the Davis court went beyond "formalized testimony or its equivalent" and thus lost the vote of Justice Thomas.

See State v. Lucas, 407 Md. 307, 965 A.2d 75 (2009) (excited statements by an assault victim, at the scene - in answer to the responding officer's questions, after telling the victim that he was "there for an investigation," asking " "what happened" " and " "where she got the marks" "- that defendant had kicked her and grabbed her around her neck were testimonial; the defendant was outside the victim's apartment, sitting on some steps; Judge Adkins, writing for a unanimous court, distinguished the case "from those in which officers encountered victims with apparent severe injuries requiring immediate medical attention and/or where an assailant had not yet been located").

refrain from criminal behavior in the presence of police sheds little, if any, light on whether his violence would have resumed had the police left without further questioning, transforming what the Court dismisses as "past conduct" back into an "ongoing emergency."

Davis v. Washington, 126 S.Ct. 2266, 2283-85 (U.S. 2006) (Thomas, J., concurring in judgment in part and dissenting in part).

8 The Davis court explained:

Although we necessarily reject the Indiana Supreme Court's implication that virtually any "initial inquiries" at the crime scene will not be testimonial, we do not hold the opposite - that no questions at the scene will yield nontestimonial answers. We have already observed of domestic disputes that "[o]fficers called to investigate ... need to know whom they are dealing with in order to assess the situation, the threat to their own safety, and possible danger to the potential victim." Hiibel, 542 U.S. at 186, 124 S.Ct. 2451. Such exigencies may often mean that "initial inquiries" produce nontestimonial statements. But in cases like this one, where Amy's statements were neither a cry for help nor the provision of information enabling officers immediately to end a threatening situation, the fact that they were given at an alleged crime scene and were "initial inquiries" is immaterial. 
D. What of Statements Not Made During Interrogation by the Police or an Agent of the Police?

\section{Elicitation by Police or Their Agents}

Justice Scalia, writing for the Crawford Court, concluded that the founders were concerned that we not repeat a practice that had occurred during "Bloody Mary's" reign in England where justices of the peace gathered ex parte statements from witnesses, and these were later offered into evidence without the accused's being given a chance to cross-examine the declarants. He remarked, "The involvement of government officers in the production of testimonial evidence presents the same risk, whether the officers are police or justices of the peace." 541 U.S. at 53. Crawford thus included as testimonial not only in-court testimony but also statements made in response to police interrogation.

In Crawford the statement in question was made in response to police interrogation at the station house. In Davis the Court expanded the definition to include some statements elicited by police at a crime scene as well as some elicited by 911 operators; it explicitly assumed that 911 operators are "law enforcement personnel," agents of the police. 547 U.S. at 817, 822, 823 n.2.

Lower courts also have found statements to be testimonial when elicited by agents of the police. E.g., Snowden, 385 Md. at 84-88, 867 A.2d at 317, 325-27 (social worker, who interviewed child victims "at a County-owned and operated facility unfamiliar to the children and used for the purpose of investigating and assessing victims of child abuse," with a police detective present in the room, and after a suspect had been identified; moreover, each child had stated that "she was aware that she was being interviewed as a result of her accusations against [the defendant]"). See also Bobadilla v. Carlson, 570 F.Supp.2d 1098 (D. Minn. 2008) (granting habeas relief on ground state court unreasonably held child's videotaped statement to a social worker in presence of a police officer was nontestimonial).

Both Crawford and Davis involved situations where the declarant knew she was speaking to police or their agents. Dictum in Crawford, 541 U.S. at 58, distinguished from the case before it Bourjaily v. United States, 483 U.S. 171, 181-84 (1987), which had upheld the admission of statements made unwittingly to an FBI informant. ..." Of course, the Bourjaily statements were statements by a coconspirator during and in furtherance of the conspiracy, which by definition were not intentionally made to the government. But the dictum indicates that the government's involvement alone is insufficient to make a speaker's statement testimonial.

\section{2. $\quad$ Statements to Others}

Again in dictum, the Crawford majority opinion states: "[N]ot all hearsay implicates the Sixth Amendment's core concerns. An off-hand, overheard remark bears little resemblance to the civil-law abuses the Confrontation Clause targeted. ... An accuser who makes a formal statement to government officers bears testimony in a sense that a person who makes a casual remark to an acquaintance does not." 541 U.S. at 51. Lower courts have fastened on to these comments and have routinely held statements to friends and family members to be 
nontestimonial. See, e.g., State v. Hosty, 944 So.2d 255 (Fla. 2006) (Florida's statutory hearsay exception for reliable statements by "an elderly person or disabled adult" as to his or her having been abused, neglected, etc., is unconstitutional as to testimonial statements only; here, initial statements by mentally retarded adult woman, to her teacher, were nontestimonial).

\section{Less Formal, More Spontaneous Statements}

Some courts have also found more spontaneous statements, not produced by formal interrogation, to be nontestimonial. See, e.g., State v. Buda, 949 A.2d 761 (N.J. 2008) (3-yearold's blurted statement to his mother, that "Daddy beats me," was nontestimonial); People v. Geno, 683 N.W.2d 687 (Mich. App. 2004), appeal denied, 688 N.W.2d 829 (Mich. 2004) (2year-old child's answer to question by non-government employee, director of Children's Assessment Center, upon seeing blood in child's "pull-up," after accompanying child to bathroom, as to whether child had "an owie," was nontestimonial).

But Davis explicitly cautions that "statements made in the absence of any interrogation are [not] necessarily nontestimonial," and that the confrontation clause will cover "volunteered testimony." 547 U.S. at 822 n.1.

\section{Excited Utterances}

\section{A. $\quad$ Are Excited Utterances Testimonial?}

\section{Crawford Cast Doubt on White v. Illinois}

Before Crawford, excited utterances ${ }^{9}$ by children were freely admitted against criminal defendants, even when the children did not testify. E.g., White v. Illinois, 502 U.S. 346 (1992). In Crawford, however, Justice Scalia commented: "One case arguably in tension with the [Crawford] rule requiring a prior opportunity for cross-examination when the proffered statement is testimonial is White v. Illinois, which involved, inter alia, statements of a child victim to an investigating police officer admitted as spontaneous declarations." 541 U.S. at 58 n.8. His remark indicated that White's precedential value was in question.

The events at issue in White began when a 4-year-old screamed in the middle of the night. Her babysitter ran to the child's second floor bedroom. On her way there, she saw the defendant emerge from the bedroom and leave the house. The child told the babysitter that the defendant had "put his hand over her mouth, choked her, threatened to whip her if she screamed

9 FRE 803(2) codifies the common law hearsay exception for out-of-court statements "relating to a startling event or condition made while the declarant was under the stress of excitement caused by the event or condition." Although there is empirical evidence that excitement impairs perception, the excitement caused by the event is thought to still reflection, so as to preclude deliberate prevarication. The requirement that the declarant remain under the stress of the exciting event up until and including the time of the statement is believed to prevent the fading of memory. The hearsay exception was recognized because of the enhanced likelihood of sincerity, the guarantee of perception, and the lack of memory problems. Under the evidence rules, excited utterances are admissible regardless whether the declarant is available to testify. 
and had 'touch[ed] her in the wrong places,'" and when asked where, pointed to her vaginal area. 502 U.S. at 349.

The babysitter telephoned the child's mother. When the mother returned home, the child told the mother the same thing, but added another detail. The mother called the police. Fortyfive minutes after the child had screamed, a police officer arrived and talked with the four-yearold at the family's kitchen table. Id. at 349-50. The Illinois court found, and the United States Supreme Court assumed, that the child's statements to her babysitter, her mother, and the police officer qualified as "spontaneous declarations" of the type referred to as excited utterances. The people who heard the child's statements testified to them at trial; the child did not testify.

The question on which certiorari was granted in White was whether the confrontation clause required that the child declarant be either produced at trial or found to be unavailable to testify before her excited utterances (as well as her subsequent statements made to a physician for the purpose of obtaining medical diagnosis or treatment) could be proved. Id. at 348-51 \& n.2. The Court's majority, in an opinion by Chief Justice Rehnquist, held that no showing of unavailability was required, and that the admission of the evidence did not impinge upon the defendant's confrontation right. Id. at 354-55 \& n.6.

The White court also held that the confrontation clause analysis applied to all hearsay evidence and rejected the government's argument that the confrontation clause did not apply, because the child's statement was not an ex parte affidavit, deposition, or confession. Id. at 352 n.5. Justice Thomas, concurring in part and concurring in the judgment, joined by Justice Scalia, would have embraced the government's argument to some degree. But, intriguingly (given subsequent developments in Crawford and Davis), the concurring opinion criticized the government's proposed test as possibly being "difficult to apply" and overbroad, on the ground that it might have included the victim's statement to the investigating officer. ${ }^{10}$

10 If not carefully formulated, however, the approach might be difficult to apply and might develop in a manner not entirely consistent with the crucial "witnesses against him" phrase. In this case, for example, the victim's statements to the investigating police officer might be considered the functional equivalent of in-court testimony because the statements arguably were made in contemplation of legal proceedings. Attempts to draw a line between statements made in contemplation of legal proceedings and those not so made would entangle the courts in a multitude of difficulties. Few types of statements could be categorically characterized within or without the reach of a defendant's confrontation rights. Not even statements made to the police or government officials could be deemed automatically subject to the right of confrontation (imagine a victim who blurts out an accusation to a passing police officer, or the unsuspecting socialservices worker who is told of possible child abuse). It is also not clear under the United States' approach whether the declarant or the listener (or both) must be contemplating legal proceedings. $* * *$ I believe it is possible to interpret the Confrontation Clause along the lines suggested by the United States in a manner that is faithful to both the provision's text and history. One possible formulation is as follows: The federal constitutional right of confrontation extends to any witness who actually testifies at trial, but the Confrontation Clause is implicated by extrajudicial statements only insofar as they are contained in formalized testimonial materials, such as affidavits, depositions, prior testimony, or confessions.

White v. Illinois, 502 U.S. at 364-65 (Thomas, J., concurring in the result and concurring in the judgment, joined by Scalia, J.) (emphasis added). 
Justice Scalia's dictum in Crawford suggested that he had changed his view to one that would include at least the child's kitchen table statements to the police officer as within the reach of the confrontation clause.

\section{Davis}

The Davis majority, again in an opinion authored by Justice Scalia, threaded the needle by holding that Amy Hammon's statements to responding police at the scene of domestic violence were testimonial, because the circumstances "objectively indicate[d] that there [was] no ... ongoing emergency, and that the primary purpose of the interrogation [was] to establish or prove past events potentially relevant to later criminal prosecution.” 547 U.S. at 822.

On the other hand, the Court held that Michelle McCottry's initial statements to a 911 operator were nontestimonial, because they were made "under circumstances objectively indicating that the primary purpose of the interrogation [was] to enable police assistance to meet an ongoing emergency." Id. Justice Scalia reasoned, "The statements in Davis were taken when McCottry was alone, not only unprotected by police, but apparently in immediate danger from Davis. She was seeking aid, not telling a story about the past. McCottry's present-tense statements ['He's here jumpin' on me again.'] showed immediacy." Id. at 817, 831.

In dictum he implied that once the immediate emergency was over, the victim's statements became testimonial:

This is not to say that a conversation which begins as an interrogation to determine the need for emergency assistance cannot, as the Indiana Supreme Court put it, "evolve into testimonial statements," once that purpose has been achieved. In this case, for example, after the operator gained the information needed to address the exigency of the moment, the emergency appears to have ended (when Davis drove away from the premises). The operator then told McCottry to be quiet, and proceeded to pose a battery of questions. It could readily be maintained that, from that point on, McCottry's statements were testimonial, not unlike the "structured police questioning" that occurred in Crawford.

Id. at 828-29. Compare Marquardt v. State, 164 Md. App. 95, 121-22, 127-28, 882 A.2d 900 (2005) (an assault victim called 911 on her cell phone and it was left on during the assault; her pleas to the defendant during the assault, which were recorded by the 911 facility, were nontestimonial; her subsequent statements made to an investigating officer at the hospital were testimonial), cert. denied, 390 Md. 91, 887 A.2d 656 (2005).

\section{Excited Utterances to Persons Not Law Enforcement Agents}

Post-Crawford, the lower courts have found excited utterances to persons other than police or their agents to be nontestimonial. E.g., People v. Vigil, 127 P.3d 916, 927-29 (Colo. 2006) (7-year-old child's excited statements to his father and his father's friends, immediately 
after sexual assault, were nontestimonial); Wallace v. State, 836 N.E.2d 985, 996 (Ind. Ct. App. 2005) (victim's statements to EMT and emergency room nurse as to who shot him were nontestimonial excited utterances and dying declarations).

\section{B. Application of Md. Rule 5-803(b)(2) in the Context of Child Declarants}

A child's utterances made while the child remains under the continuous stress of an exciting event will qualify under Md. Rule 5-803(b)(2) and its federal and other state counterparts. E.g., United States v. Sowa, 34 F.3d 447, 452-53 (7th Cir. 1994) (13-year-old's statement made 20 minutes after witnessing beating qualified); Harmony v. State, $88 \mathrm{Md}$. App. 306, 317-21, 594 A.2d 1182, 1187-89 (1991) (no abuse of discretion in admission of evidence as excited utterance, when foundational evidence supported finding that the statement, a telephone call by a crying 14-year-old girl to her sister, relating sexual abuse by their uncle that had occurred that evening, was uttered spontaneously, so that she was incapable of "forethought or deliberate design"); Moore v. State, 26 Md. App. 556, 561-67, 338 A.2d 344, 347-49 (1975) (no abuse of discretion to admit statement by 31/2-year-old child that " "Daddy was mad, Daddy did it," " made to physician in response to question, within hours after alleged beating that inflicted massive injuries).

The courts take into consideration the youth of the declarant in ascertaining whether the stress continued, unabated. E.g., Morgan v. Foretich, 846 F.2d 941, 945-48 (4th Cir. 1988) (over years from 21/2 to 4-years-old); United States v. Iron Shell, 633 F.2d 77, 83, 85-86 (8th Cir. 1980) (9-year-old who had been sexually assaulted).

Often, however, child victims' statements do not even qualify under the evidence rule, as children frequently do not disclose close enough in time to the event at issue. See Knapp v. White, 296 F.Supp.2d 766, 778 (E.D. Mich. 2003) (not improper for police officer to give expert testimony, based on past experience in similar cases, that "children often delay reporting sexual abuse").

If they disclose only upon a second event that brings the earlier startling event to mind, the requisite unbroken stress and the circumstantial guarantee of no memory problem ${ }^{11}$ are arguably missing. See Harnish v. State, 9 Md. App. 546, 266 A.2d 364 (1970) (reversing conviction because mother of 5-year-old sexual abuse victim was permitted to testify as to what child said to her -- after accused came over and asked her to send child to his home -- regarding incident which had occurred 11 days earlier). Contra, e.g., United States v. Lossiah, 129 Fed. Appx. 434 (10th Cir. 2005) (unpublished), cert. denied, 546 U.S. 954 (2005) (child under twelve's statement, upon seeing defendant arrive at school, "Don't let him check me out. He raped me [on some earlier date]." was properly admitted as an excited utterance); State v. Fowler, 500 N.E.2d 390 (Ohio App. 1985) (14-year-old child's seeing television program about incest was a startling event, so that her spontaneous statements, when found hiding in a cubbyhole in a friend's home, about sexual abuse committed on her the night before, and for years earlier, were properly admitted). In Fowler the statements were to police officers who

11 See supra note 6. 
were looking for her, one hour after she had been reported missing by her mother and stepfather, and in response to a question as to why she had run away.

Query: Even if qualifying as excited utterances, were the statements in Fowler testimonial?

\section{Statements Made in Seeking Medical Diagnosis or Treatment}

A. Qualifying Statements under the Hearsay Exception of Md. Rule 5-803(b)(4)

By virtue of Md. Rule 5-803(b)(4), the hearsay rule does not exclude those parts of statements made by a person who is seeking "medical treatment or medical diagnosis in contemplation of treatment," when they "describ[e] medical history, or past or present symptoms, pain, or sensations, or the inception or general character of the cause or external sources thereof insofar as reasonably pertinent to treatment or diagnosis in contemplation of treatment." A circumstantial guarantee of the declarant's sincerity is present only when the declarant seeks medical treatment or diagnosis in order to determine whether medical treatment is necessary. ${ }^{12}$

The courts have required a foundational showing, then, of two components: "first, is the declarant's motive consistent with the purpose of the rule; and second, is it reasonable for the physician to rely on the information in diagnosis or treatment." Iron Shell, 633 F.2d at 84.

\section{Declarant's Motive: Requisite Understanding of Medical Relevance}

The evidence must support a Md. Rule 5-104(a) finding by the court that the declarant understood that her being given appropriate medical care turned on her being completely accurate in her statements to the hearer. This standard was held to have been met, for example, in In re Rachel T., 77 Md. App. 20, 549 A.2d 27 (1988) (child was almost 5 years old, and, inter alia, she had been told by physician that the questions asked of her were to determine why she had had vaginal bleeding).

But many courts have found the required showing lacking when the declarant is a very young child. E.g., United States v. Turning Bear, 357 F.3d 730, 739 (8th Cir. 2001) (no evidence that 3-year-and-10-month-old child "understood the medical significance of being truthful"); Cassidy v. State, 74 Md. App. 1, 536 A.2d 666 (1988) (2-year-old declarant was "not mature enough to appreciate the critical cause-and-effect connections between accurate information, correct medical diagnosis, and efficacious medical treatment"). See United States $v$. Sumner, 204 F.3d 1182 (8th Cir. 2000) (reversible error to admit evidence of 6-year-old victim's statements to clinical psychologist, where although psychologist explained to victim that he was doctor, he did not discuss need for truthfulness with her or emphasize that identification of her abuser was important in his attempts to help her; there was no clear evidence that victim had

12 Maryland codified the common law hearsay exception, which is unavailable when the declarant consults a physician for other purposes, such as diagnosis (or evaluation) not intended to lead to possible treatment, which is the case when the declarant speaks with the physician solely to prepare the doctor to testify as an expert witness. See Low v. State, 119 Md. App. 413, 705 A.2d 67 (1998). 
been taken to psychologist for medical diagnosis or treatment; and victim told subsequent therapist that she saw psychologist just to talk). Cf. Rex v. Pike, 3 Car. \& Payne 598 (Assizes 1829) (4-year-old child's dying declaration was inadmissible, because she was too young to have been "under the deep impression that [she] was soon to render an account to [her] Maker").

\section{2. $\quad$ Statements Must Be "Reasonably Pertinent to Diagnosis or Treatment"}

The second component for admissibility is relevance of the information disclosed to "medical diagnosis or treatment." Two questions have arisen repeatedly in this context: (1) does "medical" include psychological? and (2) is the identity of an alleged perpetrator "pertinent" to diagnosis or treatment?

\section{a. Psychological Diagnosis or Treatment}

Sometimes the hearer of statements relevant to the patient's emotional distress is a medical doctor, in which event the courts seem to easily find medical relevance. E.g., Willingham v. Crooke, 412 F.3d 553, 561-62 (4th Cir. 2005) (abuse of discretion to exclude $\S$ 1983 plaintiff's statements to her physician reporting her anxiety due to police misconduct, on ground that they did not sufficiently relate to her physical condition; their relevance to her emotional trauma, for which she was seeking medical treatment, sufficed); United States v. Lechoco, 542 F.2d 84, 89 n.1 (D.C. Cir. 1976) (defendant's statements to his psychiatrist were admissible under Fed. R. Evid. ("FRE") 803(4)).

Whether statements to a psychologist or clinical social worker qualify as regarding "medical" treatment has caused more difficulty, though many courts have held that the Rule applies. E.g., Davignon v. Clemmey, 322 F.3d 1, 8 \& n.3 (1st Cir. 2003) (no plain error to admit intentional infliction-of-emotional-distress plaintiff's statement to a family therapist who was social worker); Swinton v. Potomac Corp., 270 F.3d 794, 808 (9th Cir. 2001) (no abuse of discretion in admitting, in racial harassment suit, psychologists' medical history summaries regarding period after plaintiff had left his job); United States v. Yellow, 18 F.3d 1438,1442 (8th Cir. 1994) (FRE 803(4) embraces statements made for psychological diagnosis); Morgan $v$. Foretich, 846 F.2d 941, 948-50 (4th Cir. 1988) (error to exclude statements made by alleged child sexual abuse victim to her psychologist for purposes of diagnosis or treatment) (retired Justice Powell dissented on this point, and would have merely had the trial court reconsider it at retrial). See United States v. Newman, 965 F.2d 206, 210 (7th Cir. 1992) (en banc) (FRE 803(4) applies to statements made to clinical psychologist) (dictum); John J. Capowski, An Interdisciplinary Analysis of Statements to Mental Health Professionals under the Diagnosis or Treatment Hearsay Exception, 33 GA. L. REV. 353, 411 (1999) (arguing that such statements should qualify). 


\section{b. $\quad$ Identity of the Culprit}

Md. Rule 5-803(b)(4) contemplates only the admission of those parts of statements pertinent to medical diagnosis or treatment, and the corollary federal Advisory Committee note explains that generally statements regarding fault will not fall within the hearsay exception.

If the health professional needed to know the source of an injury in order to determine treatment (for example, to determine what antidote was needed for a poison), the patient's statement as to source should be admissible -- particularly if the doctor told the patient that the information was necessary for proper treatment. See United States v. Narciso, 446 F. Supp. 252, 289 (E.D. Mich. 1977) (patient's statement as to who gave him an injection -- though doctor testified that it was necessary to find out that person's identity so as to learn what medication had been injected, so as to determine what treatment was required -- was not admissible under FRE 803(4), since it was not clear that patient was told this, so patient's motivation may not have been to aid in diagnosis or treatment).

Although the cases are not unanimous, many courts have concluded that the identity of a child's abuser is pertinent to the child's medical treatment. E.g., United States v. Bercier, 506 F.3d 625, 632-33 (8th Cir. 2007) ("Such statements may be admissible if the identity of the abuser is relevant to treating the victim's emotional or psychological injuries. But the government must demonstrate that (i) the physician made clear to the victim that inquiry into the abuser's identity was essential to diagnosis and treatment, and (ii) 'the victim manifest[ed] such an understanding.") (emphasis added); United States v. Edward J., 224 F.3d 1216, 1219-20 n.3 (10th Cir. 2000) (in Tenth Circuit, there is no requirement that physician first explain to child that identity of abuser is important for child's treatment); United States v. Tome, 61 F.3d 1446, 1449-51 (10th Cir. 1995) (identification of assailant is admissible when made by victim of domestic sexual abuse) (over partial dissent), rev'd on other grounds, 513 U.S. 150 (1995); United States v. Yazzie, 59 F.3d 807 (9th Cir. 1995) (mother's out-of-court statements to doctor for purposes of medical diagnosis and treatment of child for sexual abuse, which identified defendant stepfather as perpetrator, were admissible under medical treatment exception to hearsay rule); United States v. Balfany, 965 F.2d 575, 578-80 (8th Cir. 1992) (child victim's statements to medical doctor, social worker, and psychologists were admissible under FRE 803(4); identification of abuser was pertinent to doctor's recommendation for counseling and to others' diagnosis and treatment of child's emotional and psychological injuries; moreover, child testified at trial and was subject to meaningful cross-examination, so that there could be no violation of the confrontation clause); United States v. Provost, 875 F.2d 172, 176-77 (8th Cir. 1989) (proper to have admitted child sexual abuse victim's statement to physician and two psychologists that her stepbrother abused her; "The nature and extent of an abuse victim's psychological problems often depend on the identity of the abuser."); United States v. Cherry, 938 F.2d 748, 756-57 (7th Cir. 1991) (13-year-old victim's statements to doctor that defendant held her arms down, raped her, and told her not to tell anyone were admissible under FRE 803(4), because of need for treating psychological manifestations of trauma as well as physical ones); United States v. Renville, 779 F.2d 430, 438 (8th Cir. 1985) ("statements of identity to a physician by a child sexually abused by a family member are of a type physicians reasonably rely on in composing a diagnosis and course of treatment"); Williams v. Gov't of Virgin Islands, 271 F.Supp.2d 696, 704-05 n. 1 (D.V.I. 2003); State v. Vaught, 682 N.W.2d 284, 287-89, 291 
(Neb. 2004) ("Dr. Lamberty ... testified that it is important for him, in assessing the patient's condition and determining treatment, to know who the perpetrator was, both so that he does not release a patient into the care of a perpetrator and for purposes of treating the patient's mental well-being."); State v. Fisher, 108 P.3d 1262 (Wash. App. 2005), review denied, 132 P.3d 147 (Wash. 2006) (21/2-year old's statement to physician that defendant had hit him). See State v. Buda, 949 A.2d 761 (N.J. 2008) (social worker interviewed child in hospital; a social worker's "primary obligation is not to collect evidence of past events to secure the prosecution of an offender, but to protect prospectively a child in need"; her questioning of child who had suffered life threatening injuries yielded nontestimonial responses, which qualified as excited utterances; social worker took immediate steps to assure that defendant was not allowed access to child). But see Coates v. State, 405 Md. 13, 950 A.2d 114 (2008) (reversible error to admit 7-year-old's statements to pediatric nurse practitioner identifying sexual abuser, when record did not show child understood medical purpose of information); Cassidy v. State, 74 Md. App. 1, 536 A.2d 666, 682 n.14 (1988) (identity of abuser is generally inadmissible under this hearsay exception, although "When there is danger that an assault victim may have contracted a communicable disease, the identity of the assailant may take on significant medical pertinence."). See also Robert Mosteller, Child Sexual Abuse and Statements for the Purpose of Medical Diagnosis or Treatment, 67 N.C. L. REV. 257 (1989) (critiquing cases' use of FRE 803(4)).

Indeed, a jurisdiction's holding under its tort law that a patient properly states a medical malpractice claim against his treating physician for failing to prevent continual, long-term child sexual abuse by members of his household, e.g., Bentley v. Carroll, 355 Md. 312, 734 A.2d 697 (1999), would seem to compel a finding that "medical treatment" under its 5-803(b)(4)-type hearsay exception includes protection against continued child abuse.

\section{B. $\quad$ Are Md. Rule 5-803(b)(4) Statements "Testimonial”?}

The United States Supreme Court has not yet ruled on which, if any, 5-803(b)(4)-type statements are testimonial. White v. Illinois involved a child's 803(b)(4)-type statements as well as excited utterances, but the Court's opinion in Crawford singled out only the admission of the child's latter statements to the police officer as being "in tension" with the Crawford rule. Again, in dictum in Giles v. California, 128 S.Ct. at 2693, Justice Scalia wrote, "statements to physicians in the course of receiving treatment would be excluded, if at all, only by hearsay rules. ..." Yet if this were entirely so, the police could take suspected crime victims to the hospital, and prosecutors could offer all their statements that qualified under 5-803(b)(4), without ever having to worry about the confrontation clause or calling the victim to testify. Such a result, clearly circumventing Crawford, will not be accepted by the Court.

Lower courts' cases applying Crawford and Davis to 5-803(b)(4)-type statements fall into essentially two groups. One first asks, were the medical personnel acting as agents of law enforcement? If so, then was their purpose - viewed "objectively" - in questioning the child primarily to resolve an "ongoing emergency," thus yielding nontestimonial responses? Or was their primary purpose to obtain facts regarding "past events" that were "potentially relevant to later criminal prosecution" (yielding testimonial responses)? 
The other asks, even absent a connection between the police and the health professionals, was the latter's "primary purpose" medical?

Under both approaches, the ultimate question is whether the patient/declarant's primary purpose - viewed "objectively" - in giving the particular information was medical. See Davis, 547 U.S. at 822 n.1 ("[E]ven when [police] interrogation exists, it is in the final analysis the declarant's statements, not the interrogator's questions, that the Confrontation Clause requires us to evaluate.").

\section{1. $\quad$ Police Involvement Present or Inferrable}

When there is a clear nexus between law enforcement and the medical professionals - as in the case of state-paid SAFE nurses, for example, or when a child is interviewed at a governmental child abuse center, the lower courts generally have held the child's statements to have been made to an agent of the police. Most of these cases conclude that the child's statements under these circumstances are testimonial. E.g., United States v. Bordeaux, 400 F.3d 548, 555-58 (8th Cir. 2005) (child's statements in videotaped forensic interview at child abuse center, recounted by a doctor who observed the interview, were testimonial, as "the purpose was to collect information for law enforcement," even though the child's statements "may also have had a medical purpose"); State v. Blue, 717 N.W.2d 558 (N.D. 2006) (semble). See Snowden, 867 A.2d at 300 (child's statement testimonial when "made to a health or social work professional that is working in tandem with law enforcement in furtherance of ongoing and formal criminal investigation") (emphasis added).

But when the child has been brought to the hospital by police immediately following the incident at issue, some courts have found the "primary purpose" to be medical. E.g., Griner v. State, 168 Md. App. 714, 726-46, 899 A.2d 189, 201-08 (2006) (trial court found that 4-yearold's statements as to his existing eye injury to hospital nurse who admitted him to pediatric ward were nontestimonial, even though he had been taken to hospital by police; had defense preserved question, appellate court would hold that trial court ruled correctly). See Webster v. State, 151 Md. App. 527, 537-53, 827 A.2d 910, 916-25 (2003) (4-year-old child was brought to hospital by police; SAFE nurse's testimony established that the examination by her and the physician had a dual purpose: ascertainment of what treatment and diagnostic tests are necessary, and evidence collection and preservation; in this situation, then, the patient had "the requisite motive for providing the type of 'sincere and reliable' information that is important to that [medical] diagnosis and treatment").

\section{2. $\quad$ No Police Involvement}

This "nontestimonial" result has been more commonly found where there was no connection shown between the hospital and the police. See United States v. Peneaux, 432 F.3d 882, 895-96 (8th Cir. 2005), cert. denied, 549 U.S. 828 (2006) (statement made by a 3-year-old child to his pediatrician during an interview "for the purpose of ensuring his health and protection, [when] there is no evidence that the interview resulted in any referral to law enforcement," was nontestimonial); Clark v. State, 199 P.3d 1203 (Alaska App. 2009) (adult patient's statements to ER personnel that boyfriend hit her were nontestimonial; medical 
personnel's primary purpose, and declarant's in going to ER, was current need for medical diagnosis and treatment, where declarant heard something break and thought her face might become deformed); People v. Cage, 155 P.3d 205, 220 n.20 (Cal. 2007), cert. denied, 128 S.Ct. 612 (U.S. 2007) (15-year-old victim's statement to deputy sheriff who questioned him in hospital waiting room was testimonial, but victim's statement to surgeon in response to "What happened?" was nontestimonial; doctor needed to determine how to treat slash wound; statement identified defendant and was admitted under Cal. Evid. Code $\S 1370$ or as excited utterance; "primary purpose of the question, and the answer, was . . to help Dr. Russell deal with the immediate medical situation he faced."); State v. Scacchetti, 690 N.W.2d 393 (Minn. App. 2005) (statements to nurse practitioner after ER physician suspected child abuse), aff'd, 711 N.W.2d 508 (Minn. 2006) (nurse practitioner was "not a government questioner and she was not acting in concert with or as an agent of the government"); Foley v. State, 914 So.2d 677, 685 (Miss. 2005) ("neutral medical evaluation"; no showing of contact with the police or that medical personnel were being used by police); State v. Vaught, 682 N.W.2d 284, 291 (Neb. 2004) (statements to an ER physician, after child taken to hospital by family); State v. Fisher, 108 P.3d 1262, 1268-69 (Wash.App.Div.2 2005) (statement to family practice physician day after child's admission to hospital), review denied, 132 P.3d 147 (Wash. 2006).

\section{Effect of Child Abuse Reporting Requirement}

Many states' statutes require that persons knowing or reasonably suspecting abuse or neglect of a child or a vulnerable adult report that information to authorities (to law enforcement or social services). E.g., Md. Code Ann., Fam. Law $§ \S 5-704$, 5-705, 5-705.1, 14-302. Does this requirement make those who report such information "agents of law enforcement," such that a child or vulnerable adult's statement to those persons may be considered testimonial? In a state such as Maryland, where the duty to report extends to all persons, id. $\S 5-705$, accepting that argument would make everyone in Maryland potentially such an agent. Concluding that every citizen is a government agent seems clearly at odds with Crawford's historical rationale.

The California Supreme Court has held that a reporting requirement did not make a child's statement to his physician, that his mother had cut his face with a piece of glass, testimonial. The court reasoned:

[T] he reporting statute does not oblige a doctor to investigate or ascertain, for purposes of possible criminal prosecution, whether a patient has suffered such abuse. The physician's sole duty is to make a report "whenever [he or she] in his or her professional capacity or within the scope of his or her employment, has knowledge of or observes a child whom the [physician] knows or reasonably suspects has been the victim" of abuse or neglect.

The mere fact that doctors must report abuse they see, suspect, or know of in the course of practice does not transform them into investigative agents of law enforcement. Nor does it convert their medically motivated questions during the examination of minor patients into investigatory interrogations that elicit testimonial responses. Here, despite Dr. Russell's incidental status as a mandatory reporter of suspected abuse, "the circumstances objectively indicate" 
that the "primary purpose" of his question, and John's answer, was to pinpoint the nature of a serious acute injury in order to provide immediate treatment, not to establish, for potential criminal purposes, that John was abused. [FN As defense counsel conceded at oral argument, defendant's "mandatory reporter" argument would mean that certain statements by a 17-year-old patient to a treating physician are automatically testimonial, while an 18-year-old patient's identical statements, made under identical circumstances for identical reasons, are not. We see no basis to reach such an illogical conclusion.]

People v. Cage, 155 P.3d 205, 219-20 \& n.19 (Cal. 2007) (emphasis in original) (citation omitted), cert. denied, 128 S.Ct. 612 (2007). See State v. Buda, 949 A.2d 761, 779-80 (N.J. 2008) (under circumstances of case, statements to mandatory reporter, social worker, were not testimonial). Contrast with Cage the facts of People v. Stechly, 870 N.E.2d 333 (Ill. 2007) (plurality decision) (5-year-old child's statements to her mother on ride to hospital were nontestimonial, but child's statements to "mandatory reporters" of child abuse were testimonial, where nurse and social worker's comments focused on making reports, and they took no other action) and State v. Henderson, 160 P.3d 776 (Kan. 2007).

The lower California appellate court in Cage, affirmed by the California Supreme Court, reasoned:

No reasonable person in John's shoes would have expected his statements to Dr. Russell to be used prosecutorially, at defendant's trial. This is true even if he thought the doctor might relay his statements to the police. After all, anyone who obtains information relevant to a criminal investigation might (and certainly should) pass it along [to] the police. This possibility, standing alone, does not suffice to make hearsay testimonial within the meaning of Crawford.

15 Cal. Rptr. 3d 846, 855 (Cal. App. 4th Dist. 2004), aff'd, 155 P.3d 205 (Cal. 2007), cert. denied, 128 S.Ct. 612 (U.S. 2007).

\section{VII. "Tender Years" and "Catch-All" Exceptions}

Because statements of young children recounting their abuse often do not qualify under the more "firmly rooted" hearsay exceptions, most state legislatures have adopted "tender years" exceptions. See, e.g., Snowden, 867 A.2d 314 (Md. 2005) (8 and 10-year-old childrens' statements were testimonial). California also has a sui generis exception, which was applied in Giles, for statements by any victims of recent physical injury or threat of injury. Cal. Evid. Code $\S 1370$.

Absent such statutory provisions, other states and the federal courts have employed the "catch-all" exception of FRE 807 and its state counterparts like Md. Rule 5-803(b)(24) for statements of child abuse victims not falling under more specific hearsay exceptions. E.g., Idaho v. Wright, 497 U.S. 805 (1990) (state court committed reversible error depriving the defendant of the right of confrontation by admitting, under the state equivalent of FRE 807, doctor's 
testimony to $2 \frac{1}{2}$-year-old child's insufficiently reliable statements, identifying the defendant and her codefendant as the child's abusers).

\section{Admissibility of Prior Consistent Statements When Declarant Testifies; State Law Hearsay Exception for Prompt Complaints of Sexual Assault}

Tome v. United States, 513 U.S. 150 (1995) creates an insurmountable "catch-22" for child abuse victims. Tome held that it was reversible error to admit, under FRE 801(d)(1)(B), a young child's prior consistent statements recounting the charged abuse, on the ground that they preceded the motive alleged by the defendant, her father, to fabricate: that she wanted to live with her mother. Upon the mere assertion by the defense of the existence of that motive, it would have been impossible for any of the child's prior statements to have qualified under the Rule, as construed by the majority. See, e.g., United States v. Bercier, 506 F.3d 625, 629-33 (8th Cir. 2007) (reversible error to admit prior consistent statements of sexual assault victim). 13 The Court of Appeals of Maryland has followed Tome in construing Md. Rule 5-802.1(B). Holmes v. State, 350 Md. 412 (1998).

But Md. Rule 5-802.1(d) recognizes a hearsay exception for a victim's prompt reports of sexual assault, where the victim testifies at trial and is subject to cross-examination concerning the statement, would be beneficial. Id. See, e.g., Nelson v. State, 137 Md. App. 402, 768 A.2d 738 (2001) (13-year-old girl's statement to her 11-year-old sister, made shortly after defendant left their apartment, that defendant had raped her, qualified for admission under Md. Rule 5802.1(d); victim's statements a day later to her school counselor and to a nurse-sexual assault examiner would likely also have so qualified, but no objections to them were preserved). This exception, unlike Md. Rule 5-802.1(B), has the decided advantage for the prosecution that it (like 803 and 804 hearsay exceptions) does not require that the victim testify consistently with the outof-court statement.

\section{Maryland's Hearsay Exceptions Derived from Fed. R. Evid. 804(b)(6): A Criminal Statute and a Civil Rule}

\section{A. The Criminal Statute}

The Maryland forfeiture-hearsay exception statute, Md. Cts. \& Jud. Proc. Code Ann. \$ 10-901, was originally adopted in $2005 .{ }^{14}$ Its kernel contains the "intent-to-prevent"

13 Tome is explicitly based only on construction of FRE 801(d)(1)(B), and not on any constitutional requirement. The Rule, therefore, can and should be amended to encompass all prior consistent statements (subject to FRE 403 and 611(a)) that would be helpful to a reasonable jury in evaluating what effect, if any, to give to impeachment of an alleged child abuse victim evidence. See Lynn McLain, Post-Crawford: Time to Liberalize the Substantive Admissibility of a Testifying Witness's Prior Consistent Statements, 74 UMKC L. REV. 1 (2005). 14 The Maryland statute recognizes the following hearsay exception:

(a) During the trial of a criminal case in which the defendant is charged with a felonious violation of Title 5 of the Criminal Law Article or with the commission of a crime of violence as defined in 14-101 of the Criminal Law Article, a statement as defined in Maryland Rule 5-801(a) is not excluded by the hearsay rule if the statement is offered against a party that has engaged in, directed, or conspired to commit wrongdoing that was intended to and did procure the 
testimony requirement of FRE 804(b)(6), but jettisons the "acquiescence" terminology in favor of "directed or conspired in. ..."

\section{1. $\quad$ Restrictive in Scope: Types of Cases}

Due to amendments made to Governor Ehrlich's original bill by the House Judiciary Committee, unlike the corollary FRE 804(b)(6), the Maryland statute is restricted so as to apply only to trials for certain crimes. The statute applies only to crimes involving either drug distribution ("felonious violations of Title 5 of the Criminal Law Article") or those that qualify as "crimes of violence as defined in 14-101 of the Criminal Law Article." The latter category does not include, for example, second degree assault (which is often charged in domestic violence cases).

This unprecedented restrictive approach has engendered piecemeal annual amendments. In the 2006 session $\S 14-101$ of the Criminal Law article was amended to include "child abuse in the first degree under \$ 3-601 of [the Criminal Law] article" as a "crime of violence." In 2007 the General Assembly added "sexual abuse of a minor under $\$$ 3-602 of [the Criminal Law] article if: (i) the victim is under the age of 13 years and the offender is an adult at the time of the offense; and (ii) the offense involved: (1) vaginal intercourse, as defined in $\S 3-301$ of this article; (2) a sexual act, as defined in $\$ 3-301$ of this article; (3) an act in which a part of the offender's body penetrates, however slightly, into the victim's genital opening or anus; or (4) the intentional touching, not through the clothing, of the victim's or the offender's genital, anal, or other intimate area for sexual arousal, gratification, or abuse" and "continuing course of

unavailability of the declarant of the statement, as defined in Maryland Rule 5-804.

(b) Subject to subsection (c) of this section, before admitting a statement under this section, the court shall hold a hearing outside the presence of the jury at which:

(1) The Maryland Rules of Evidence are strictly applied; and

(2) The court finds by clear and convincing evidence that the party against whom the statement is offered engaged in, directed, or conspired to commit the wrongdoing that procured the unavailability of the declarant,

(c) A statement may not be admitted under this section unless:

(1) The statement was:

(i) Given under oath subject to the penalty of perjury at a trial, hearing, or other proceeding or in a deposition;

(ii) Reduced to writing and signed by the declarant; or

(iii) Recorded in substantially verbatim fashion by stenographic or electronic means contemporaneously with the making of the statement; and

(2) As soon as is practicable after the proponent of the statement learns that the declarant will be unavailable, the proponent notifies the adverse party of:

(i) The intention to offer the statement;

(ii) The particulars of the statement; and

(iii) The identity of the witness through whom the statement will be offered. 
conduct with a child under $§$ 3-315 of the Criminal Law article.”

\section{2. $\quad$ Departure from Usual Procedure under Md. Rule 5-104(a)}

The Maryland statute provides that, unlike the procedure followed in federal court, or in other preliminary determinations by State trial judges (outside the hearing of the jury) as to admissibility of evidence under Md. Rule 5-104(a), the other Maryland Rules of evidence (including the hearsay rule) will be "strictly applied" at this preliminary stage. This provision virtually guts the bill. An intimidated or dead witness will not appear to testify to her intimidation or murder. The preliminary facts regarding the opposing party's wrongdoing thus must be proved either by the testimony of another witness who has first-hand knowledge of them, or by the unavailable witness's out-of-court statements that qualify under a hearsay exception, such as that for excited utterances.

Secondly, unlike the ordinary burden of a preponderance of the evidence with regard to proof of preliminary facts, the statute applies a burden of "clear and convincing evidence." Before the adoption of this statute, the Maryland case law had applied the clear and convincing standard only to preliminary proof of an accused's Md. Rule 5-404(b) "other crimes," which is then to be admitted before the jury, the trier of fact. Under the forfeiture hearsay exception, in contrast, the jury does not hear of the party's wrongdoing that made the witness unavailable, but only of the unavailable declarant's out-of-court statement. (It should be noted, however, that evidence of that wrongdoing might come in under a preexisting, independent route, such as that of wrongful acts showing "guilty knowledge." See Md. Rule 5-804(b)(5), Committee Note.)

\section{3. $\quad$ Restrictive in Scope: Types of Out-of-Court Statements}

The types of statements potentially admissible under the Maryland law is narrowed from those permissible under FRE 804(b)(6), to only recorded or written and signed statements (the same types that also are potentially substantively admissible prior inconsistent statements under Md. Rule 5-802.1(a), when the declarant testifies at trial).

Thus, statements made by those witnesses who were murdered preemptively or intimidated before their statements were recorded or written and signed are not included under the Maryland codifications, as they would be under federal law. See United States v. Rivera, 292 F. Supp. 2d 827 (E.D. Va. 2003) (declarant's oral statements to her guardian and attorney).

\section{4. $\quad$ Notice}

The Maryland law adds a requirement that the proponent of the evidence must provide notice of its intent to offer evidence under this hearsay exception.

\section{B. The Civil Rule}

The hearsay exception provision applicable in civil cases, new Md. Rule 5-804(b)(5), which became effective January 1, 2006, incorporates the "directed or conspired" language, the notice requirement, and the restriction as to types of statements that are codified in the Maryland 
criminal statute. ${ }^{15}$ The Rule, however, does not restrict the types of civil cases to which the Rule applies; nor does it change the procedure typically followed under Md. Rule 5-104(a).

\section{Other Significant Developments}

\section{A. $\quad$ Melendez-Diaz}

Melendez-Diaz v. Massachusetts, 129 S.Ct. 2527 (2009) (state lab certificate of drug analysis was testimonial, but some indication that a notice and demand statute like Maryland's will be upheld). Cf. Briscoe v. Virginia, cert. granted, 129 S.Ct. 2858 (U.S. No. 09-11191) (attacking Virginia's statute, which provides for the accused to call the analyst as his or her own witness).

\section{B. $\quad$ Rule 5-802.1(a): Certain Prior Inconsistent Statements}

To clarify that the declarant's adoption by signature will suffice, and that the declarant need not have been the one to reduce the statement to writing, Md. Rule 5-802.1(a)(2) was amended by order of November 8, 2005, effective January 1, 2006, to read: "A statement that is inconsistent with the declarant's testimony if the statement was ... (2) reduced to writing and was signed by the declarant. ..."

\section{C. $\quad$ Rule 5-802.1(c): Prior Statements of Identification}

See Jones v. State, 395 Md. 97, 909 A.2d 650 (2006) (reversible error to preclude defense from calling detective who presented photo array to testify at suppression hearing).

15 Md. Rule 5-804(b)(5) provides:

(b) Hearsay Exceptions. The following are not excluded by the hearsay rule if the declarant is unavailable as a witness:

$* * *$

(5) Witness Unavailable Because of Party's Wrongdoing

(A) Civil Actions. In civil actions in which a witness is unavailable because of a party's wrongdoing, a statement that (i) was (a) given under oath subject to the penalty of perjury at a trial, hearing, or other proceeding or in a deposition; (b) reduced to writing and was signed by the declarant; or (c) recorded in substantially verbatim fashion by stenographic or electronic means contemporaneously with the making of the statement, and (ii) is offered against a party who has engaged in, directed, or conspired to commit wrongdoing that was intended to, and did, procure the unavailability of the declarant as a witness, provided however, the statement may not be admitted unless, as soon as practicable after the proponent of the statement learns that the declarant will be unavailable, the proponent makes known to the adverse party the intention to offer the statement and the particulars of it.

(B) Criminal Causes. In criminal causes in which a witness is unavailable because of a party's wrongdoing, admission of the witness's statement under this exception is governed by Code, Courts Article, $\S 10-901$. 


\section{Rule 5-803(a): Statement of Party Opponent}

See Brown v. Daniel Realty Co., 2009 WL 2085548 (Md. Jul. 22, 2009) (a deponent is a "party," for purposes of Md. Rule 2-419(a)(2) permitting a litigant to use an adverse party's deposition for any purpose, only if the deponent remains a party at the time that the deposition is offered into evidence; child's next friend was not a "party").

\section{E. $\quad$ Rule 5-803(b)(3): Direct Assertion of Declarant's State of Mind}

See Figgins v. Cochrane, 174 Md. App. 1, 27-31, 920 A.2d 572 (2007) (Hillmon analysis inapplicable when no contention that declarant subsequently acted in accord with stated intent), aff'd, 403 Md. 392, 942 A.2d 736 (2008).

\section{F. $\quad$ Rule 5-803(b)(6): Business Records}

Hall v. University of Maryland Medical Sys. Corp., 398 Md. 67, 919 A.2d 1177 (2007) (reversible error to exclude statements written by doctors, reporting what nurses and residents had said, regarding pathologically germane information).

\section{G. $\quad$ Rule 5-803(b)(8): Public Records/"Business Records" of the State?}

In Rollins v. State, the Court of Appeals affirmed a Court of Special Appeals' decision that "the findings in an autopsy report of the physical condition of a decedent, which are routine, descriptive and not analytical, [and] which are objectively ascertained" were non-testimonial. The medical examiner-declarant had moved to California and did not testify, but his deputy medical examiner testified, basing her testimony on the autopsy report. The trial court had redacted some of the original medical examiner's opinions regarding "disease ... [,] smothering ... [and] homicide . . by asphyxiation." In an opinion by Judge Greene, a unanimous Court of Appeals held:

[T]he autopsy report, as redacted, contained non-testimonial hearsay statements in nature that were admissible under either the business or public records exceptions to the hearsay rule. We further hold that, under the facts of the instant case, the availability of a witness is immaterial to the question of admissibility of hearsay evidence under either the business or public records exception. Opinions, speculation, and other conclusions drawn from the objective findings in autopsy reports are testimonial and should be redacted before the report is admitted into evidence.

$$
* * *
$$

The information that was not redacted from the autopsy report, while it might eventually be used in a criminal trial, was not created for that express purpose, and was statutorily required to be determined by the medical examiner and placed into the report pursuant to $\S 5-311$ of the Health General Article.

In contrast to Rollins, see United States v. Feliz, 467 F.3d 223 (2d Cir. 2001) (finding autopsy reports to be nontestimonial business records and public records and affirming 
conviction, when only a doctor from the medical examiner's office who had not conducted the autopsies testified at trial as to the autopsies).

With a focus on the routine nature of the statement, the United States Court of Appeals for the Ninth Circuit has held that public records contained in the accused's "penitentiary packet" - records of his convictions, his fingerprints and a photograph - were not testimonial. Moreover, their certification as accurate copies of those public records, by the Oklahoma records custodian and by Oklahoma's Secretary of State, were also routine, non-testimonial statements, United States v. Weiland, 420 F.3d 1062, 1076-77 (9th Cir. 2005), cert. denied, 126 S.Ct. 1911 (U.S. 2006).

\section{H. $\quad$ Rule 5-804(b)(2): Dying Declarations}

In its first post-Davis decision, the Court of Special Appeals relied on Davis to conclude that a dying declaration was nontestimonial (but see supra n.3). In Head v. State, $171 \mathrm{Md}$. App. 642, 912 A.2d 1 (2006), cert. denied, 395 Md. 315, 920 A.2d 1059 (2007), the first police officer arriving at the scene of a shooting asked the victim, "Who shot you?" The victim, who died within the hour, answered "Bobby."

Judge Salmon, writing for the panel in a manner reminiscent of Louis L'Amour, pointed out "the strong smell of gunpowder still in the air." That fact, coupled with the officer's testimony that the victim "kept 'yelling out' the words 'help me, help me,", "the situation was "chaotic,"” the officer " "didn't even know if . . the person who caused that gunpowder was still in the house," and "in the officer's view, it was still 'potentially even a dangerous situation. . . ,"' led the panel to conclude that the statement was nontestimonial under Davis, because, "Viewed objectively, the primary purpose of Officer George's question does not appear to have been either to establish or prove past events for possible use at a trial."

\section{I. $\quad$ Rule 5-805: Multiple Levels of OCS's Within One OCS}

See Cooley v. State, 157 Md. App. 101, 111, 849 A.2d 1026 (2004), rev'd on other grounds, 385 Md. 165, 867 A.2d 1065 (2005) (one level of OCS was nonhearsay and the other was hearsay falling within an exception).

\section{J. Doctor's Apology}

Md. Cts. \& Jud. Proc. Code Ann. § 10-920 provides that expressions "of regret or apology" - as opposed to admissions "of liability or fault" - made by or on behalf of a health care provider are "inadmissible as evidence of an admission of liability or as evidence of an admission against interest."

\section{K. Impeachment of Nontestifying Hearsay Declarants: Md. Rule 5-806}

Taylor v. State, 407 Md. 137, 963 A.2d 197 (2009), held that impeachment of a key, nontestifying declarant by extrinsic evidence of a prior bad act under Md. Rule 5-608(b) must be allowed, if it would be permitted if the declarant had testified at trial. 


\section{Hypotheticals}

\section{Are the following statements testimonial?}

a. A domestic violence victim's excited utterance to a police officer who arrives at her door? If she is saying, "He's got a gun!"

b. A 911 call by a witness to a stabbing? If he is seeking an ambulance? If he is seeking police assistance?

c. A police lab technician's report on a defendant's blood alcohol level? The DNA of blood found at a crime scene?

d. A hospital report as to blood analysis of a "regular" patient? Of a patient brought in by police for DUI?

e. (i) If a neighbor asks to have a 7-year-old child come over "to help around the house" and the child tells his mother, "I don't want to go! He did something bad to me last time," is the child's statement testimonial?

(ii) If the mother calls Social Services and takes the child in for an interview because of suspected child abuse, are the child's statements to the social worker testimonial? Does it matter whether a police officer is present during the interview? If the officer is in plain clothes and the child does not know that s/he is an officer?

(iii) Would it matter if the social worker was employed by a private agency or a church, rather than the local government?

(iv) If the mother instead takes the child to the hospital, are the child's statements to the doctor and nurses - describing the abuse and identifying the abuser - testimonial? Of what import is it that all Maryland citizens have a duty to report child abuse? See Griner v. State, 168 Md. App. 714, 899 A.2d 189, 20108 (2006).

(v) Does it matter whether the child is 3 , or 7 , or 12 ?

f. Is a mentally disabled victim who is called by the prosecution - to demonstrate her limited mental capacity, rather than to testify to the alleged crime against her - a witness under the Sixth Amendment? (P.G. County trial, Feb. 2006).

g. With regard to whether a domestic violence victim's statement is testimonial, is it significant that many/most DV victims do not cooperate with the prosecution at trial? Would they cooperate long enough to have a preliminary hearing?

h. Is pleading with a domestic violence victim not to testify "wrongdoing"? Can one 
get a "no contact" order pending trial?

i. Is a letter, "to be opened in the event of my death," testimonial?

j. What about a statement of fear to a friend, "I'm afraid my husband is going to kill me one of these days"? Testimonial or not?

\section{Appendix: Fact Patterns}

Stoddard v. State, 887 A.2d 564 (Md. 2005)

Erik (boyfriend of Calen's mother) had been babysitting 3-year-old Calen, her older brother, and her cousin, 11/2-year-old Jasmine, on the day Calen died.

In Erik's trial for Calen's murder, prosecution calls Jasmine's mother to testify that though they had never discussed Erik's involvement - after Calen's death, Jasmine became afraid of strangers and loud noises [wincing, hiding, and crying] and began having nightmares and running into her mother's room, asking, "Is Erik going to get me?"

$$
* * *
$$

\section{Griner v. State, 899 A.2d 189 (Md. 2006)}

At 10:00 a.m., two police officers responded to a call requesting they check on the welfare of 4-2/3-year-old Chase, who was being raised by his grandmother-defendant, as her own child. They saw that Chase's right eye was swollen and partially shut; he had a cut above the eye, with stitches in it.

Grandmother said that Chase had fallen at a skating rink, and he had received medical attention. When Grandmother permitted one officer to speak separately with Chase, he said he had fallen on a step. When asked, Chase said he had not gone to a doctor; defendant had stitched the cut. Police called for an ambulance to have paramedics examine Chase's eye.

Ambulance took Chase to hospital. Both an officer and defendant followed in their vehicles. County social worker questioned Chase at 12:00 noon. Chase said he hurt his eye when he fell on the ice at a skating rink. When the LCSW asked Chase about his "mom," Chase said that she hit him a lot "all over," with a "pow stick," a cane, and a belt. He said that she hit him in the eye with the pow stick the preceding day, and that she stitched the cut above his eye. Chase said that defendant would tie him to his bed and that once, while tied up, he had gone 3 days without food: he would be untied to use the bathroom, and he had been given water, because he apologized.

A police detective arrived, spoke with the LCSW, and then interviewed Chase, while various doctors and nurses were in and out of the room as they attended to Chase's 
medical needs. [When asked by a doctor what happened, Chase said he had fallen. When Chase became upset, doctor ceased questioning.] Chase was admitted to hospital. A registered Nurse saw Chase in the pediatric ward after he was sent from the ER. Nurse found Chase's right eye to be "really swollen and red" and that he had two sutures above the eye. Nurse introduced herself as a nurse, explained to Chase that she was going to take care of him, and that she would examine him from "head to toe." Nurse asked Chase if he could open his injured eye wide enough to see clearly, and Chase said that he could. She touched the eye lightly and noted that "it was pretty warm to the touch." She noted that "he had various scars and bruises throughout his body." The scars "were like U- and C-shaped marks."

When Nurse asked Chase what happened to his eye, he replied that he had fallen. Upon seeing the other bruises and scars, she asked Chase if he was sure he had fallen. Chase responded: "[W]ell actually my mom hit me with a stick." When Nurse asked why his mom hit him, Chase answered that it was because he had been "a bad boy" and had not done his "math and spelling lessons." Nurse asked Chase about the scars on his body, and he stated that his mom had hit him with a stick.

Chase was released from the hospital and taken to a foster home the next day. Twelve days later, a Department of Health and Human Services pediatrician examined Chase, in the presence of the LCSW. When the doctor asked what happened, he stated that his mother hit him with a stick because he was bad and did not do his math.

Upon removing Chase's clothing, the doctor observed "all these bruises, old scars really, of injury to his skin." He had "linear scars" on his body and "loop marks" on his back and thighs. Chase indicated that he had gotten the loop marks on his thighs when appellant hit him with an "electric." Chase also said that appellant had hit him with a stick on his eye and that no one else had hit him.

The doctor testified at trial that she did not ask Chase leading questions and did not suggest to him what had happened to him. She opined that, due to the location of the loop marks and the pattern of marks, the marks were intentionally inflicted and were consistent with having been caused by use of an electrical cord.

$$
* * *
$$

\section{State v. Fowler, 500 N.E.2d 390 (Ohio 1985)}

On October 14, at 7:00 p.m., Kimberly, a 14-year-old girl, was reported missing to the police by her mother and stepfather. An hour later, the child was located at a friend's residence and officers were dispatched to that address. They located Kimberly hiding behind some boxes in an upstairs cubbyhole. Her aspect was described as upset and scared. When the police asked why she had run away from home, Kimberly related that her stepfather had involved her in ongoing acts of incest, imposing oral sex upon her. She told police that she had seen a movie that evening called "Something About Amelia" 
which dealt with the problem of incest, and at that time she realized "what had been going on in her life."

Kimberly was relayed to the police station where she provided a written statement alleging that her stepfather initiated sexual activity with her when she was a third grader. She indicated that she had most recently been importuned by him the previous evening.

Kimberly did not testify at trial.

\section{Idaho v. Wright, 497 U.S. 805 (1990)}

51/2-year-old girl told her father's girlfriend that her mother held her down while her mother's boyfriend has sexual intercourse with her, and that she had seen them do the same thing to her $2^{1} / 2$-year-old sister (who was living with defendants). Father's girlfriend made a police report and took 51/2-year-old to hospital. Dr. Jambura found medical evidence of sexual abuse.

Police and welfare officials then took $2 \frac{1}{2} 2$-year-old into protective custody. The following day, Dr. Jambura found physical evidence "strongly suggestive of sexual abuse with vaginal contact," occurring approximately 2 or 3 days earlier. He testified that he asked the $2 \frac{1}{2}$-year-old a series of questions, about breakfast, etc., then culminating in "Does daddy touch you with his pee-pee?" She responded that he did, "but he does it a lot more with my sister than with me."

$$
* * *
$$

State v. Buda, 949 A.2d 761 (N.J. 2008)

When defendant (child's mother's boyfriend) came to pick up 3-year-old, child started crying. Child was routinely picked up by his mother and did not cry.

Compare if child had said, "I'm afraid of defendant," or "I'm afraid of defendant, because he beats me."

(For detailed discussions of the hearsay case law, see LynN MCLAIN, Vol. 6A MARYLAND EVIDENCE: STATE AND FEDERAL §§ 801:1 et seq., (2d ed. 2001 \& Supp. 2009) (available online at Westlaw; input the volume number then "Maryland Evidence" and then the section number you seek). To purchase a copy - of the treatise and annual pocket parts (vols. 5, 6, and 6A) - or of the 2007 edition of the Rules book (vol. 7), please contact the publisher at 1-800-344-5009.) 
